\title{
14. CENOZOIC NANNOFOSSILS, CENTRAL EQUATORIAL PACIFIC, DEEP SEA DRILLING PROJECT LEG 851
}

\author{
Annick Pujos, Département de Géologie et Océanographie, Institut de Géologie du Bassin d'Aquitaine²
}

\begin{abstract}
Leg 85 of the Deep Sea Drilling Project recovered Cenozoic nannofossils from the central and eastern parts of the Pacific equatorial high-productivity area. The low-latitude zonation of Bukry (1973a) was used for dating uppermost Eocene to uppermost Pliocene samples. At two sites (573 and 574) the Eocene/Oligocene boundary was reached, enabling accurate study in spite of an unconformity and strong calcite dissolution. Some unconformities and/or intervals of very low rates of sedimentation are described in detail and correlated from one site to another. The high abundance of species belonging to Reticulofenestra and Dictyococcites permitted the accurate study of these taxa; their morphologic differences and their stratigraphic occurrences are described in detail. A short, tentative, ecological study was made by using the nannofossil dissolution index, the total nannofossil abundance, and the abundance of some taxa. The easternmost site (Site 572) contains some species that are restricted to this site and are characteristic of upwelling areas. Discoasters are totally absent in a sediment interval apparently deposited during a period of unstable climate when glacial to interglacial oscillations were occurring in Antarctica.
\end{abstract}

\section{INTRODUCTION}

Leg 85 of the Deep Sea Drilling Project began at San Pedro, California, and ended at Honolulu, Hawaii (Fig. 1). Five sites were drilled, but only four of them provided Cenozoic material (Sites 572 to 575). A light microscope (with a phase contrast and a Nomarski interferential system) was used for studying about 1000 nannofossil samples with the smear-slide technique. All the slides were quickly reviewed for determining zonal boundaries; abundances of nannofossils were estimated on most of them, and the abundance of a few taxa was estimated with more precision for ecological studies (see range charts for count scales). The species (and a few genera for which the species were indeterminate) are listed in alphabetic order in the Appendix. Coccolith zonation is based on Bukry (1973a) and Okada and Bukry (1980) and is summarized in Figure 2. Nannofossil zonal assignment is given in Table 1 . Coccoliths provide an almost continuous biostratigraphic record at the four sites. Occasionally, a zone or subzone is not well defined, usually because of the absence of stratigraphic markers. Few unconformities were evident; they are indicated in the site summaries. Dissolution was also estimated; the solution index given in the Quaternary study (Pujos, this volume) is used for the placoliths only. The usual scarcity of discoasters does not allow the precise study of dissolution and/or etching on these incertae sedis. Nannofossil total abundance was evaluated by observing two fields $(\times 100)$. Variations in abundance are not directly related to nannofossil dissolution and therefore may provide information on productivity and ecology.

\footnotetext{
${ }^{1}$ Mayer, L., Theyer, F., et al., Init. Repts. DSDP, 85: Washington (U.S. Govt. Printing Office).

2 Address: Institut de Géologie du Bassin d'Aquitaine, Université de Bordeaux I, Avenue des Facultés, 33405 Talence Cedex, France.
}
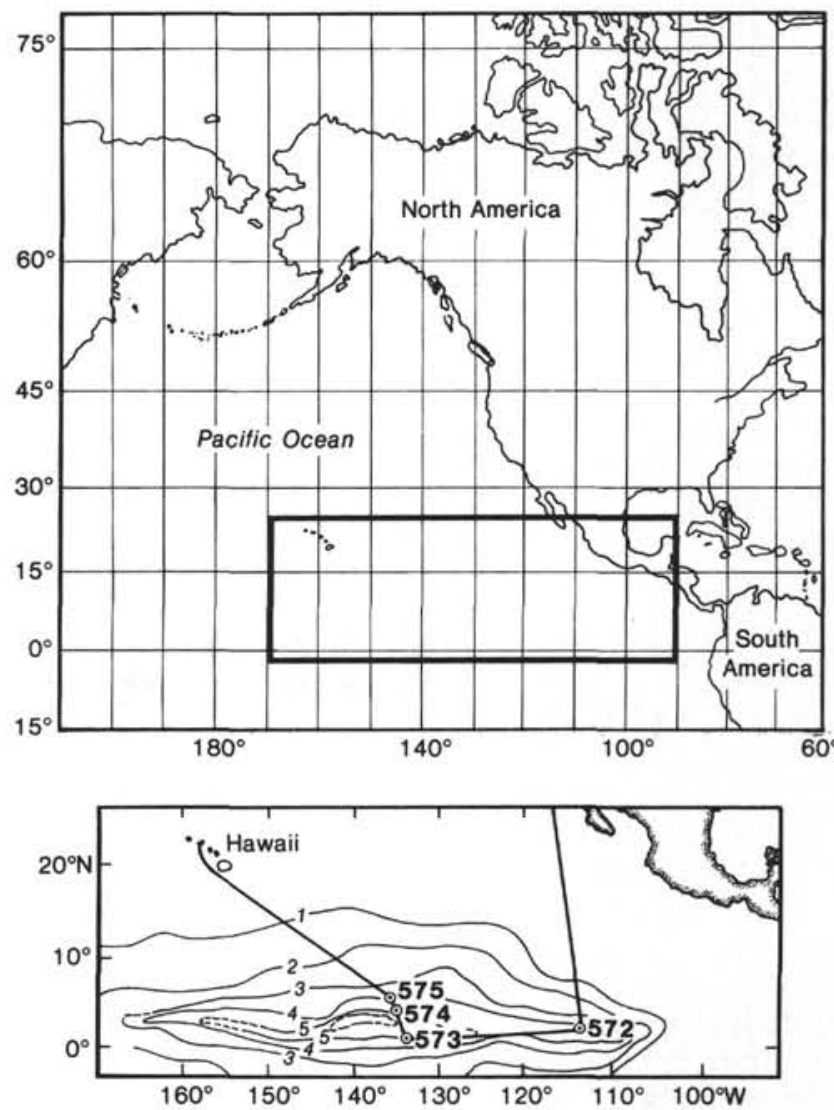

Figure 1. Location of DSDP Leg 85 in the equatorial high-productivity area, with blow-up at bottom showing detailed location of sites.

Species identification and abundance estimates were made in approximately 1000 samples; the results for selected samples, which were chosen as being typical of the various assemblages, are reported in Tables 2 to 5 . 


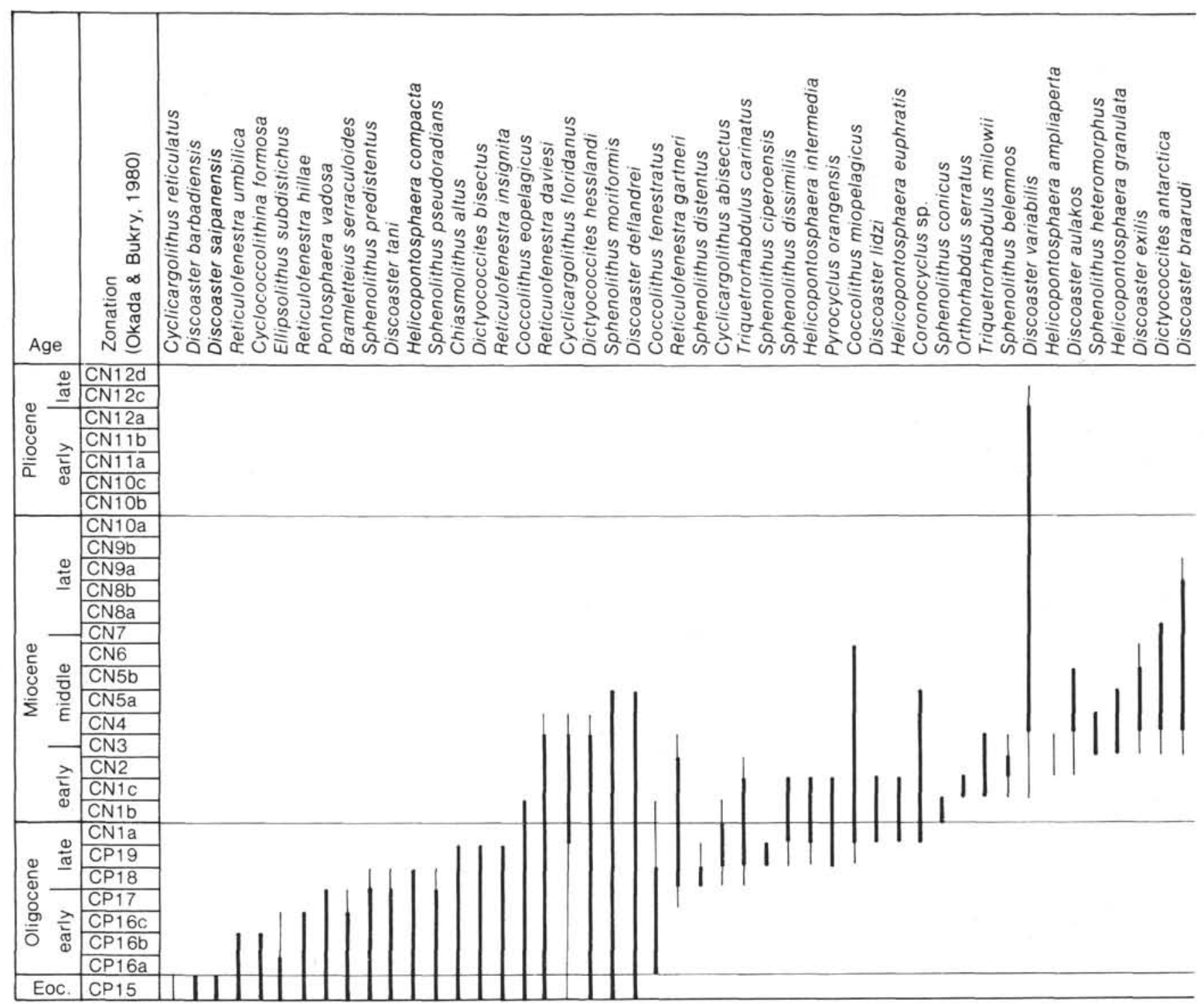

Figure 2. Stratigraphic ranges of selected nannofossils present in the Cenozoic sequence of Leg 85 (zonation from Okada and Bukry, 1980).

\section{SUMMARY OF THE SITES}

\section{Site $\mathbf{5 7 2}$}

Site 572 (Table 2 and Fig. 3) was cored in the eastern part of the equatorial high-productivity area $\left(1^{\circ} 26.1^{\prime} \mathrm{N}\right.$, $113^{\circ} 50.5^{\prime} \mathrm{W} ; 3903 \mathrm{~m}$ sub-bottom). Five holes were drilled and 76 cores were recovered. Holes $572 \mathrm{~A}$ and $572 \mathrm{D}$ provide a continuous sequence from lower middle Miocene to the top of the Pliocene. Coccoliths are usually common to very abundant in all samples, but dissolution has resulted in significant and frequent variations. Placoliths are occasionally very poorly preserved (e.g., Cores 572A-7, 572D-14, and 572D-17), and sometimes they do not show any sign of dissolution (Cores 572A10, 572A-15, 572A-16, 572D-5, and 572D-16). This complete absence of dissolution at some levels is exceptional in the high-productivity area, where calcite is usually not well preserved. The excellent state of preservation at Site 572 may be due to its location at the periphery of the productive area, where the ecological factors causing calcite dissolution are not effective continuously. Discoasters are especially scarce at this site; they are usually completely absent or represented by less than $0.5 \%$ of the whole population. Thus, they cannot be used for zonation except in the Sphenolithus neoabies and Discoaster asymmetricus subzones (including D. brouweri, $D$. surculus, and $D$. decorus), in the $D$. berggrenii Subzone (having a small bloom of the zonal species), and in the $D$. bellus Subzone (containing frequent $D$. bollii). Reworked coccoliths from the Eocene/Oligocene boundary are common in the middle Miocene (from the bottom of Hole 572D up to Core 572D-24). Above the Coccolithus miopelagicus Subzone, reworking is sporadic.

Most of the zones from the middle Miocene to the top of the Pliocene were identified biostratigraphically. This identification was not always easy because of the dominance of various members of the Gephyrocapsaceae family in all samples. Besides common species such as Reticulofenestra pseudoumbilica, $R$. doronicoides, $R$. haquii, and $R$. minutula, there is a huge abundance of 


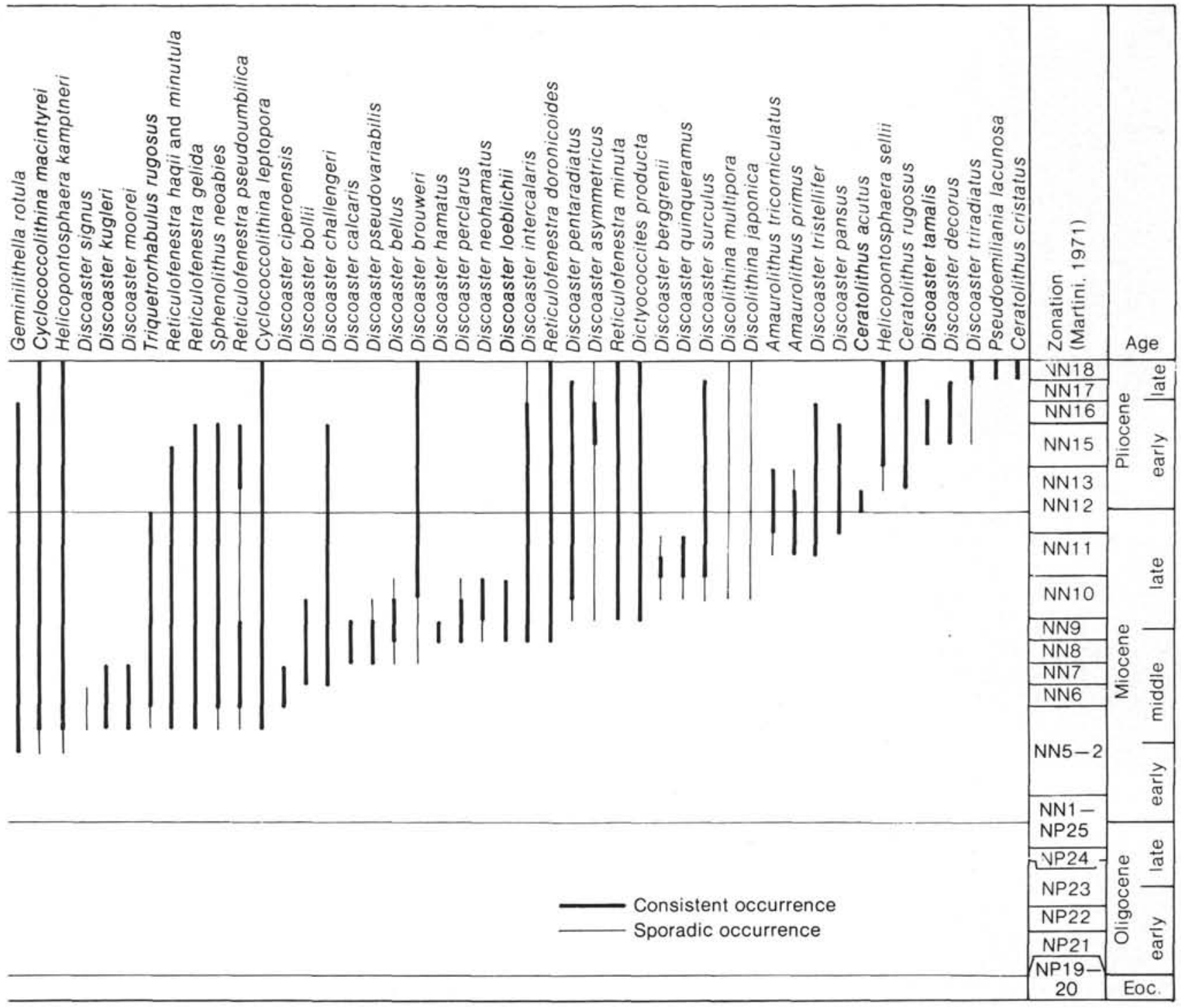

Figure 2. (Continued).

small elliptical coccoliths belonging to $R$. minuta and " $R$." tagana, which tend to hide the other taxa throughout the stratigraphic column. This abundance of small Reticulofenestra and the reduced number of discoasters are considered by Lohmann and Carlson (1981) to be characteristic of cooler waters. Moreover, " $R$." tagana has been noted only in upwelling areas (Fonseca, 1976, in Portugal; Bukry, 1981, in sediments off the coast of California and Mexico). Therefore, nannofossil assemblages at Site 572 are apparently strongly influenced by special ecological factors such as upwelling (Barron, this volume). This may explain the presence of some taxa that are completely absent from the other sites of Leg 85: some Pontosphaera spp. (e.g., P. multipora and P. japonica), Scyphosphaera spp., and Syracosphaera spp. have a sporadic distribution, whereas Geminithella rotu$l a$ is almost continuously present in all cores.

The Catinaster calyculus and Discoaster bellus subzones are condensed to a thin interval of sediment, probably resulting from a very low rate of sedimentation.
Furthermore, there is evidence that a low rate of sedimentation occurred throughout the Pliocene and the late Miocene. A strong change in this rate apparently occurred between middle and late Miocene: for the interval from Core 572D-16 to the bottom of the hole, the rate of sedimentation was apparently very high.

The oldest zone identified at Site 572 is the Sphenolithus heteromorphus Zone (14 to $15 \mathrm{Ma}$ ). The same age was attributed to the bottom sediment recovered at most of the sites of Leg 63, which were drilled at about the same longitude (but at much higher latitudes). This result is in accordance with the tectonic setting of the area.

\section{Site 573}

Site 573 (Table 3 and Fig. 3) is located in the eastern part of the equatorial high-productivity area $\left(00^{\circ} 29.9^{\prime} \mathrm{N}\right.$, $133^{\circ} 18.57^{\prime} \mathrm{W} ; 4317 \mathrm{~m}$ sub-bottom), in the vicinity of Site 77 of Leg 9. Three holes were drilled, providing 68 cores dated from latest Eocene to Pleistocene. Nannofossils were studied in Holes 573 and 573B. 
Table 1. Summary of nannofossil zonal assignments for Leg 85 . In the last four columns, the two numbers given for each zonal interval represent the hole, core, section, and depth of the highest and lowest samples delineating that zone or subzone (zonation of Okada and Bukry, 1980).

\begin{tabular}{|c|c|c|c|c|c|c|c|}
\hline \multicolumn{2}{|c|}{ Age } & Zones & Subzones & Site 572 & Site 573 & Site 574 & Site 575 \\
\hline \multicolumn{2}{|l|}{ Pleistocene } & $\begin{array}{l}\text { CN13 Crenalithus } \\
\text { doronicoides }\end{array}$ & CN13a Emiliania annula & $572 \mathrm{~A}-4-1,139 \mathrm{~cm}$ & $573-4-6,40 \mathrm{~cm}$ & $574-2-3,100 \mathrm{~cm}$ & $575-1-3,120 \mathrm{~cm}$ \\
\hline \multirow{7}{*}{ Pliocene } & \multirow{3}{*}{ late } & \multirow{3}{*}{ CN12 Discoaster brouweri } & CN12d Cyclococcolithus macintyrei & $\begin{array}{l}572 \mathrm{~A}-4-2,20 \mathrm{~cm} \\
572 \mathrm{~A}-4-3,20 \mathrm{~cm}\end{array}$ & $\begin{array}{l}573-4-6,60 \mathrm{~cm} \\
573-5, \mathrm{CC}\end{array}$ & $\begin{array}{l}574-2-3,120 \mathrm{~cm} \\
574-2-4,60 \mathrm{~cm}\end{array}$ & $\begin{array}{l}575-1-3,140 \mathrm{~cm} \\
575-1-4,60 \mathrm{~cm}\end{array}$ \\
\hline & & & $\mathrm{CN} 12 \mathrm{c}$ Discoaster pentaradiatus & $\begin{array}{l}572 \mathrm{~A}-4-4,20 \mathrm{~cm} \\
572 \mathrm{~A}-5-3,0 \mathrm{~cm}\end{array}$ & $\begin{array}{l}573-6-2,0 \mathrm{~cm} \\
573-6-5,0 \mathrm{~cm}\end{array}$ & $\begin{array}{l}574-2-4,80 \mathrm{~cm} \\
574-2-6,60 \mathrm{~cm}\end{array}$ & $\begin{array}{l}575-1-4,140 \mathrm{~cm} \\
575-1-5,60 \mathrm{~cm}\end{array}$ \\
\hline & & & CNI2a Discoaster tamalis & $\begin{array}{l}572 \mathrm{~A}-5-4,0 \mathrm{~cm} \\
572 \mathrm{~A}-6-6,0 \mathrm{~cm}\end{array}$ & $\begin{array}{l}573-7-2,0 \mathrm{~cm} \\
573-7-3,0 \mathrm{~cm}\end{array}$ & $\begin{array}{l}574-2-6,83 \mathrm{~cm} \\
574-3-5,27 \mathrm{~cm}\end{array}$ & $\begin{array}{l}575-1, \mathrm{CC} \\
575-2-1,35 \mathrm{~cm}\end{array}$ \\
\hline & \multirow{4}{*}{ early } & \multirow{2}{*}{$\begin{array}{l}\text { CN11 Reticulofenestra } \\
\text { pseudoumbilica }\end{array}$} & CNIIb Discoaster asymmetricus & $\begin{array}{l}572 \mathrm{~A}-6-7,0 \mathrm{~cm} \\
572 \mathrm{~A}-7-3,0 \mathrm{~cm}\end{array}$ & \multirow[t]{2}{*}{$573-7-4,0 \mathrm{~cm}$} & $574-3-6,27 \mathrm{~cm}$ & $575-2-1,115 \mathrm{~cm}$ \\
\hline & & & CNI1 a Sphenolithus neoabies & \multirow[t]{2}{*}{$\begin{array}{l}572 \mathrm{~A}-8-3,0 \mathrm{~cm} \\
\text { ?Dissolution }\end{array}$} & & $574-4-3,27 \mathrm{~cm}$ & $575-2-3,115 \mathrm{~cm}$ \\
\hline & & \multirow{3}{*}{$\begin{array}{l}\text { CN10 Amaurolithus } \\
\text { tricorniculatus }\end{array}$} & $\mathrm{CN} 10 \mathrm{c}$ Ceratolithus rugosus & & \multirow[t]{2}{*}{$573-8-7,0 \mathrm{~cm}$} & $574-4.4 .27 \mathrm{~cm}$ & $\begin{array}{l}575-2-4,35 \mathrm{~cm} \\
575-2-4,35 \mathrm{~cm}\end{array}$ \\
\hline & & & CN10b Ceratolithus acutus & $572 \mathrm{~A}-10, \mathrm{CC}$ & & & $575-2-4,115 \mathrm{~cm}$ \\
\hline \multirow{14}{*}{ Miocene } & \multirow{6}{*}{ late } & & CN10a Triquetrorhabdulus rugosus & $572 \mathrm{~A}-13, \mathrm{CC}$ & $573-10-5,0 \mathrm{~cm}$ & $574-5-2,29 \mathrm{~cm}$ & $575-3-1,35 \mathrm{~cm}$ \\
\hline & & \multirow{2}{*}{$\begin{array}{l}\text { CN9 Discoaster } \\
\text { quinqueramus }\end{array}$} & CN9b Amaurolithus primus & $\begin{array}{l}572 \mathrm{~A}-14-3,0 \mathrm{~cm} \\
572 \mathrm{~A}-17-3,0 \mathrm{~cm}\end{array}$ & $\begin{array}{l}573-10, \mathrm{CC} \\
573-12-2,0 \mathrm{~cm}\end{array}$ & \multirow{2}{*}{$\begin{array}{l}574-5-3,29 \mathrm{~cm} \\
\text { Dissolution } \\
574-6-1,29 \mathrm{~cm}\end{array}$} & \multirow{2}{*}{$\begin{array}{l}575-3-2,35 \mathrm{~cm} \\
575-3 \cdot 4,35 \mathrm{~cm}\end{array}$} \\
\hline & & & CN9a Discoaster berggrenii & $\begin{array}{l}572 \mathrm{~A}-17, \mathrm{CC} \\
572 \mathrm{D}-2, \mathrm{CC}\end{array}$ & $\begin{array}{l}573-12-3,0 \mathrm{~cm} \\
573-13-1,0 \mathrm{~cm}\end{array}$ & & \\
\hline & & \multirow{2}{*}{$\begin{array}{l}\text { CN8 Discoaster } \\
\text { neohamatus }\end{array}$} & CN8b Discoaster neorectus & \multirow{2}{*}{$\begin{array}{l}572 \mathrm{D}-3-1,50 \mathrm{~cm} \\
572 \mathrm{D}-14-3,55 \mathrm{~cm}\end{array}$} & $\begin{array}{l}573-13-2,0 \mathrm{~cm} \\
573-15-3,0 \mathrm{~cm}\end{array}$ & \multirow[t]{2}{*}{$574-6-2,28 \mathrm{~cm}$} & $\begin{array}{l}575-3-5,35 \mathrm{~cm} \\
575-3-6,35 \mathrm{~cm}\end{array}$ \\
\hline & & & CN8a Discoaster bellus & & $\begin{array}{l}573-15-4,0 \mathrm{~cm} \\
573 \mathrm{~B}-4-2,15 \mathrm{~cm}\end{array}$ & & $\begin{array}{l}575-3, C C \\
575-4-1,28 \mathrm{~cm}\end{array}$ \\
\hline & & \multicolumn{2}{|c|}{ CN7 Discoaster hamatus } & $\begin{array}{l}572 \mathrm{D}-14-4,55 \mathrm{~cm} \\
572 \mathrm{D}-16-3,55 \mathrm{~cm}\end{array}$ & $\begin{array}{l}573 \mathrm{~B}-4-3,15 \mathrm{~cm} \\
573 \mathrm{~B}-4, \mathrm{CC}\end{array}$ & $\begin{array}{l}574-9-1,49 \mathrm{~cm} \\
574-10-3,49 \mathrm{~cm}\end{array}$ & $575-4-2,35 \mathrm{~cm}$ \\
\hline & \multirow{8}{*}{ middle } & \multicolumn{2}{|c|}{ CN6 Catinaster coalitus } & $\begin{array}{l}572 \mathrm{D}-16-4,55 \mathrm{~cm} \\
572 \mathrm{D}-19-2,47 \mathrm{~cm}\end{array}$ & $\begin{array}{l}573 \mathrm{~B}-5-1,15 \mathrm{~cm} \\
573 \mathrm{~B}-6-2,15 \mathrm{~cm}\end{array}$ & $\begin{array}{l}574-10-4,49 \mathrm{~cm} \\
574-12-1,49 \mathrm{~cm}\end{array}$ & $\begin{array}{l}575-4-3,35 \mathrm{~cm} \\
575-4-6,35 \mathrm{~cm}\end{array}$ \\
\hline & & \multirow{2}{*}{ CN5 Discoaster exilis } & CN5b Discoaster kugleri & $\begin{array}{l}572 \mathrm{D}-19-3,47 \mathrm{~cm} \\
572 \mathrm{D}-24-2,55 \mathrm{~cm}\end{array}$ & $\begin{array}{l}573 \mathrm{~B}-6-3,15 \mathrm{~cm} \\
573 \mathrm{~B}-7-1,15 \mathrm{~cm}\end{array}$ & $\begin{array}{l}574-12-2,49 \mathrm{~cm} \\
574-13-2,49 \mathrm{~cm}\end{array}$ & $\begin{array}{l}575-5-1,35 \mathrm{~cm} \\
575-5-4,35 \mathrm{~cm}\end{array}$ \\
\hline & & & CNSa Coccolithus miopelagicus & $\begin{array}{l}572 \mathrm{D}-24-3,55 \mathrm{~cm} \\
572 \mathrm{D}-27, \mathrm{CC}\end{array}$ & $\begin{array}{l}573 \mathrm{~B}-7-2,15 \mathrm{~cm} \\
573 \mathrm{~B}-9-3,15 \mathrm{~cm}\end{array}$ & $\begin{array}{l}574-14-3,49 \mathrm{~cm} \\
573-16-2,34 \mathrm{~cm}\end{array}$ & $\begin{array}{l}575-5-5,35 \mathrm{~cm} \\
575-8-3,35 \mathrm{~cm}\end{array}$ \\
\hline & & \multicolumn{2}{|c|}{ CN4 Sphenolithus heteromorphus } & \multirow{13}{*}{$\begin{array}{l}\text { 572D-28,CC } \\
\text { Not reached }\end{array}$} & $\begin{array}{l}573 \mathrm{~B}-9-4,15 \mathrm{~cm} \\
573 \mathrm{~B}-12-4,15 \mathrm{~cm}\end{array}$ & $\begin{array}{l}574-16-3,34 \mathrm{~cm} \\
574-28-3,49 \mathrm{~cm}\end{array}$ & $\begin{array}{l}575-8-4,35 \mathrm{~cm} \\
575-9-4,35 \mathrm{~cm}\end{array}$ \\
\hline & & CN3 Helicop & ntosphaera ampliaperta & & $\begin{array}{l}573 \mathrm{~B}-12-5,15 \mathrm{~cm} \\
573 \mathrm{~B} \cdot 14-2,15 \mathrm{~cm}\end{array}$ & $\begin{array}{l}574-28, C C \\
574 C-3-2,49 \mathrm{~cm}\end{array}$ & $\begin{array}{l}575-9, \mathrm{CC} \\
575 \mathrm{~A}-6-1,51 \mathrm{~cm}\end{array}$ \\
\hline & & $\mathrm{CN} 2 \mathrm{Sph}$ & nolithus belemnos & & $\begin{array}{l}573 \mathrm{~B}-14-3,15 \mathrm{~cm} \\
573 \mathrm{~B}-17-2,15 \mathrm{~cm}\end{array}$ & $\begin{array}{l}574 \mathrm{C}-3-3,49 \mathrm{~cm} \\
574 \mathrm{C}-5-3,49 \mathrm{~cm}\end{array}$ & $\begin{array}{l}575 \mathrm{~A}-6 \cdot 2,51 \mathrm{~cm} \\
575 \mathrm{~A}-7-3,51 \mathrm{~cm}\end{array}$ \\
\hline & & & CN1c Discoaster druggii & & $\begin{array}{l}573 \mathrm{~B}-17-3,15 \mathrm{~cm} \\
573 \mathrm{~B}-20-6,25 \mathrm{~cm}\end{array}$ & $\begin{array}{l}574 C-5-4,49 \mathrm{~cm} \\
574 C-10-1,49 \mathrm{~cm}\end{array}$ & $\begin{array}{l}575 \mathrm{~A}-8-2,51 \mathrm{~cm} \\
575 \mathrm{~A}-13, \mathrm{CC}\end{array}$ \\
\hline & & $\begin{array}{c}\text { CN1 Triquetrorhabdulus } \\
\text { carinatus }\end{array}$ & CNIb Discoaster deflandrei & & 573B-20,CC & $\begin{array}{l}574 C-10-2,49 \mathrm{~cm} \\
574 C-16-3,49 \mathrm{~cm}\end{array}$ & $575 \mathrm{~A}-14-2,5 \mathrm{~cm}$ \\
\hline \multirow{7}{*}{ Oligocene } & \multirow{3}{*}{ late } & & CN1a Cyclicargolithus abisectus & & $573 \mathrm{~B}-20, \mathrm{CC}$ & $\begin{array}{l}574 C-16, C C \\
574 C-17-2,49 \mathrm{~cm}\end{array}$ & \multirow[t]{8}{*}{ Not reached } \\
\hline & & CP19 Sph & nolithus ciperoensis & & $\begin{array}{l}573 \mathrm{~B}-21-1,30 \mathrm{~cm} \\
573 \mathrm{~B}-26-1,15 \mathrm{~cm}\end{array}$ & $\begin{array}{l}574 C-17-3,49 \mathrm{~cm} \\
574 C-23-1,39 \mathrm{~cm}\end{array}$ & \\
\hline & & CP18 Sp & enolithus distentus & & $\begin{array}{l}573 \mathrm{~B}-26-2,17 \mathrm{~cm} \\
573 \mathrm{~B}-34-2,19 \mathrm{~cm}\end{array}$ & $\begin{array}{l}574 C-23-2,39 \mathrm{~cm} \\
574 C-27-2,27 \mathrm{~cm}\end{array}$ & \\
\hline & & CP17 Sphe & nolithus predistentus & & $\begin{array}{l}573 \mathrm{~B}-35, \mathrm{CC} \\
573 \mathrm{~B}-38-2,27 \mathrm{~cm}\end{array}$ & $\begin{array}{l}574 C-27-3,25 \mathrm{~cm} \\
574 C-29-1,35 \mathrm{~cm}\end{array}$ & \\
\hline & early & & CP16c Reticulofenestra hillae & & $\begin{array}{l}573 \mathrm{~B}-38-3,27 \mathrm{~cm} \\
573 \mathrm{~B}-41, \mathrm{CC}\end{array}$ & $\begin{array}{l}574 C-29-2,34 \mathrm{~cm} \\
574 C-32-2,49 \mathrm{~cm}\end{array}$ & \\
\hline & & $\begin{array}{c}\text { CP16 Helicopontosphaera } \\
\text { reticulata }\end{array}$ & CP16b Coccolithus formosus & & $\begin{array}{l}573 B-42-1,20 \mathrm{~cm} \\
573 B-42-2,50 \mathrm{~cm}\end{array}$ & $574 \mathrm{C}-32-3,49 \mathrm{~cm}$ & \\
\hline & & & CPI6a Coccolithus subdistichus & & $573 \mathrm{~B}-42-4,71 \mathrm{~cm}$ & $574 \mathrm{C}-33-4,114 \mathrm{~cm}$ & \\
\hline Eocene & & CP15 Dis & oaster barbadiensis & & $\begin{array}{l}573 \mathrm{~B}-42-4,58 \mathrm{~cm} \\
573 \mathrm{~B}-42-4,135 \mathrm{~cm}\end{array}$ & $574 \mathrm{C}-33-5,5 \mathrm{~cm}$ & \\
\hline
\end{tabular}

Note: No nannofossils were found at 573B-42-4, $10 \mathrm{~cm}$ (dashed boundary).

Coccolith assemblages are usually abundant and diverse but often dissolved. Nannofossils in the Eocene sediments of this site are rare and usually show much dissolution and/or etching. Oligocene and early middle Miocene coccoliths are common to very abundant and are moderately dissolved. Coccoliths are less abundant and more dissolved in the upper Miocene. There is a thin section containing abundant and well-preserved coccoliths in the lowermost Pliocene. Rapid and continuous evolution can be recognized up to the upper middle 
Pliocene, where dissolution has destroyed almost all coccoliths. The uppermost Pliocene shows the opposite situation; the top of the Cenozoic section is rich in well preserved nannofossils.

Discoasters are not abundant at this site. When present, they are often dissolved and/or etched, and most of them cannot be identified to the species level, nor are they useful for zonation. In only one case was the general morphologic outline useful: from the top of the Cenozoic to the Sphenolithus heteromorphus Zone (early middle Miocene), the discoaster assemblages are dominated by long-rayed specimens. Below this level (from the Helicopontosphaera ampliaperta Zone), short-rayed discoasters are much more abundant, and they are often the only discoasters present. This differentiation is also useful for the other sites. Reworking is not common at this site, although some Eocene coccoliths or discoasters are found sporadically below the middle upper Miocene.

Almost all zones of Bukry's zonation were found between Zone CP15b (latest Eocene) and CN12d (latest Pliocene). Some subzones could not be identified clearly in the lower Pliocene (within the Reticulofenestra pseudoumbilica Zone and the Amaurolithus tricorniculatus Zone) because of the absence or scarcity of the subzonal markers (e.g., Triquetrorhabdulus rugosus, Ceratolithus acutus, C. primus, Discoaster asymmetricus, D. tamalis, and $D$. decorus). At the same levels, some species indicative of cooler water, such as $D$. variabilis, are frequent. The apparent arrival of cool water may explain the absence of cosmopolitan and warm water taxa. The rate of sedimentation appears to have been constant throughout this interval.

By using the nannofossil occurrences and the rates of sedimentation, it is possible to identify three periods of hiatus, or at least very low rates of sedimentation. (1) The rate of sedimentation was apparently low in the early late Miocene, from 9 to $13 \mathrm{Ma}$, but the corresponding nannofossil zones do exist for this interval. If there actually is a hiatus here, it may occur within a single zone, more specifically in the earliest part of the $D$. bellus Subzone. This phenomenon is noted not only at Sites 574 and 575, but also in wide areas of the Pacific (Keller, 1981). (2) The Cyclicargolithus abisectus Subzone is missing and the $D$. deflandrei Subzone is present in the uppermost Oligocene only between Sample 573D-20,CC and 573D-21-1, 30-31 cm. The underlying zone (Sphenolithus ciperoensis Zone) is apparently almost complete. The hiatus occurs approximately between 21 and $24 \mathrm{Ma}$, as was already noted by Hays et al. (1972) at Site 77. (3) The lowermost hiatus corresponds to a barren, metalliferous claystone unit. There are no coccoliths or discoasters between 573D-42-4, $10 \mathrm{~cm}$ and 573D-42-2, $71 \mathrm{~cm}$. Above this barren unit, at the interval between 573D-42-2, $71 \mathrm{~cm}$ and 573D-42-1, 20-21 cm, abundant nannofossils characterize the lower Oligocene (Coccolithus formosus Subzone), but the lowermost Oligocene subzone ( $C$. subdistichus Subzone) is absent. Below the barren sediment, a thin layer of sediment (573D-42-4, $58-135 \mathrm{~cm}$ ) is attributed to the Eocene; nannofossils are scarce and poorly preserved in this interval, and disco- asters are strongly etched. Isthmolithus recurvus was not found. Bukry (1975) noted that this species "can be considered a consistent marker fossil only at latitudes higher than $30^{\circ}$ north or south. It is typically absent at tropical sites and is best considered a restricted subzonal marker." The attribution of these samples to $D$. barbadiensis Zone is based on the presence of a few D. saipanensis in the interval 573D-42-4, 58-105 cm and D. saipanensis and $D$. barbadiensis in the interval 573D-42-4, $110-135 \mathrm{~cm}$. In summary, the oldest sediments of Hole 573D present this succession:

\begin{tabular}{|c|c|c|c|}
\hline$\underline{57} \underline{1}-\underline{\mathrm{D}}-\underline{-2}-2, \underline{50} \mathrm{~cm}$ & Subzone $\mathrm{CP} 16 \mathrm{~b}$ & & Oligocene \\
\hline $\begin{array}{l}573 \mathrm{D}-42-2,71 \mathrm{~cm} \\
\text { to } 573 \mathrm{D}-42-4,10 \mathrm{~cm}\end{array}$ & \multicolumn{2}{|c|}{ Barren sediment } & \\
\hline $573 \mathrm{D}-42-4,58-105 \mathrm{~cm}$ & D. saipanensis & Zone & \\
\hline 573D-42-4, $110-135 \mathrm{~cm}$ & $\begin{array}{l}\text { D. saipanensis and } \\
\text { D. barbadiensis }\end{array}$ & CP15 & Eocene \\
\hline
\end{tabular}

It is not possible to date the barren sediment precisely in this succession. In addition to Subzone CP16a (which is not represented in the nannofossil associations), most of Subzone CP16b and the uppermost part of Zone CP15 may be also missing. In observing the marked change in the sedimentation rate corresponding to this period (Fig. 3), it becomes obvious that it is much more than simply a hiatus in the biozonation, but a real unconformity in sedimentation that can be more precisely defined as occurring between 573D-42-2, $50 \mathrm{~cm}$ and 573D$42-4,58 \mathrm{~cm}$.

Such a succession is typical in the equatorial eastern Pacific (Bukry, pers. comm., 1983), where the Eocene/ Oligocene boundary commonly occurs within barren sediment. This hiatus is known to be extensive in the Pacific (Kennett et al., 1975). For Bukry (1973a), Subzone CP16a "may be missing as a result of ecological factors." Kennett et al. (1975) link it with the beginning of Antarctic glaciation, which caused increased circulation of Antarctic Bottom Water.

\section{Site 574}

Site 574 (Table 4 and Fig. 3) was drilled within the central Pacific high-productivity area, just north of the crest of the sediment bulge $\left(4^{\circ} 12.52^{\prime} \mathrm{N}, 139^{\circ} 19.81^{\prime} \mathrm{W}\right.$; $4548 \mathrm{~m}$ sub-bottom). The four holes of the site provided 92 cores. Holes 574 and $574 \mathrm{C}$ were chosen for the study of Cenozoic nannofossils ranging from the uppermost Eocene to the uppermost Pliocene. From the lowest Oligocene to the upper middle Miocene, coccoliths are often abundant and moderately etched; above this section, nannofossils are extensively etched and are common to rare. This advanced dissolution that appears at the top of the middle Miocene $(\sim 13 \mathrm{Ma})$ most likely is related to the end of the time of equatorial crossing (van Andel et al., 1975). From the end of the middle Miocene, Site 574 was located north of the equator under the influence of corrosive waters. Only the most resistant of the solution-resistant species can be found in the section representing this time. For example, Coccolithus pelagicus is usually absent in the upper Miocene and the Plio- 
Table 2. Occurrence and estimated abundance of nannofossils in selected samples from Site 572.

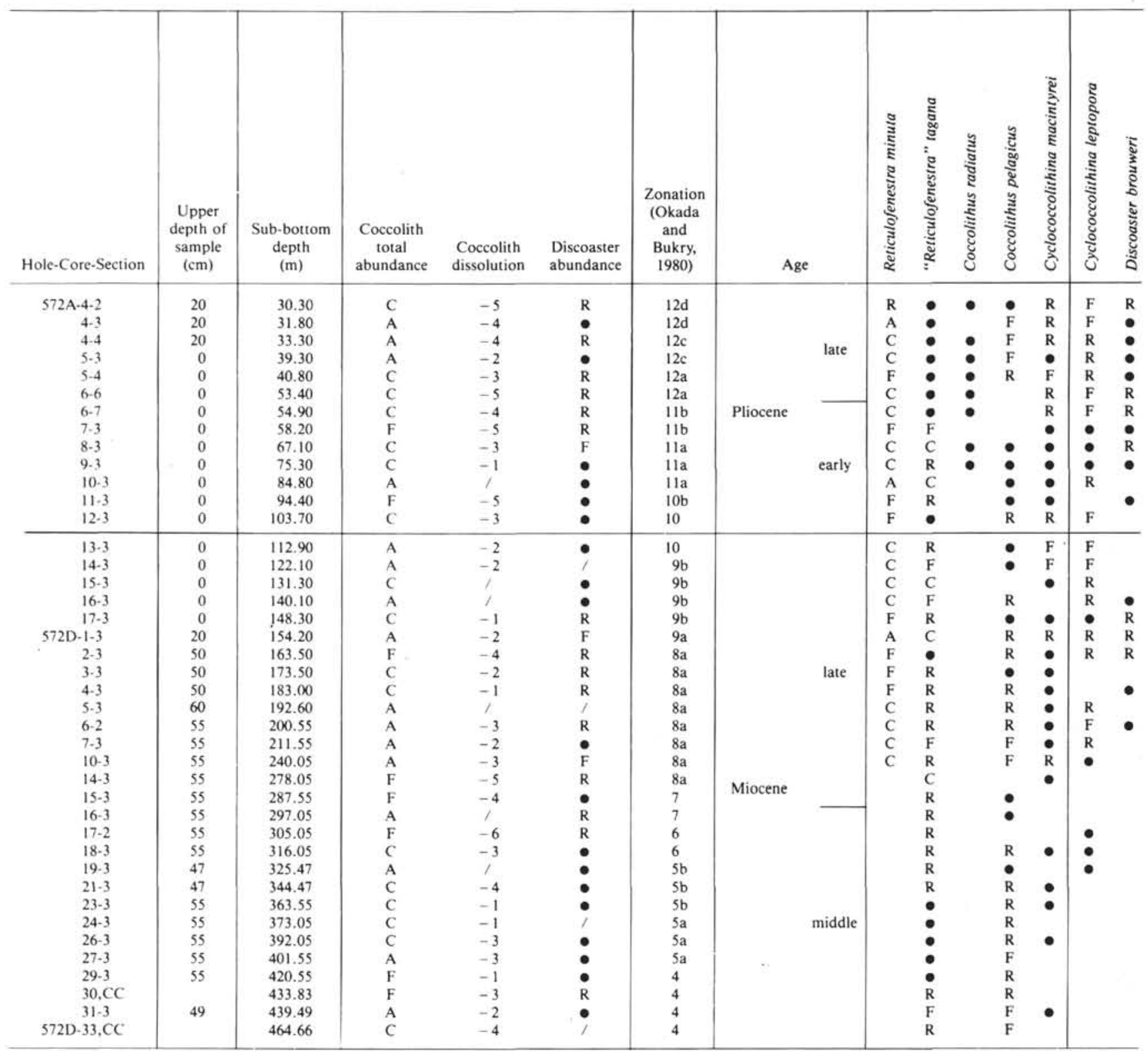

Notes: Abundance of species is indicated as follows: - very rare, $\mathrm{R}=$ rare $=$ one specimen in $>10$ fields of view; $\mathrm{F}=$ few $=$ at least one specimen in 5 to 10 fields of view; $\mathrm{C}=$ common $=$ at least one specimen in 1 field of view; $\mathrm{A}=$ abundant $=$ numerous specimens in 1 field of view; ()$=$ reworked specimens; ${ }^{*}=\mathrm{cf}$. Index of solution is as follows (see discussion of Quaternary, Pujos, this volume): $/=$ no dissolution, $-1=$ few coccoliths slightly dissolved, $-2=$ most coccoliths are slightty dissolved, $-3=$ most coccoliths are moderately dissolved, -4 coccoliths are strongly dissolved, $-5=$ no intact coccoliths, and -6 only ghosts of coccoliths.

cene, while Cyclococcolithina leptopora and C. macintyrei still persist.

Discoasters are not abundant at this site. They are very scarce in the Sphenolithus heteromorphus Zone, although Coccolithus pelagicus is common. This assemblage is attributable to the influence of cool waters. In the Amaurolithus tricorniculatus Zone and the Reticulofenestra pseudoumbilica Zone, discoasters are more abundant. This is most likely due to the acme of certain species, such as Discoaster tristellifer and D. pentaradiatus, which are warmer water species, and $D$. variabilis and $D$. intercalaris, which are cooler water species. This spe- cific duality may reflect a climatic duality controlled by the ecological complexity of the area.

Reworking occurs throughout the section at Site 574 but is never significant. It is, however, noteworthy in three intervals: (1) in the middle Miocene, the Coccolithus miopelagicus Subzone contains abundant Reticulofenestra hillae reworked from the Eocene/Oligocene boundary; (2) in the lower middle Miocene, there is a notable number of coccoliths reworked from the Oligocene/Miocene boundary; and (3) there is a constant reworking of Eocene nannofossils in all the Oligocene assemblages. 
Table 2. (Continued).

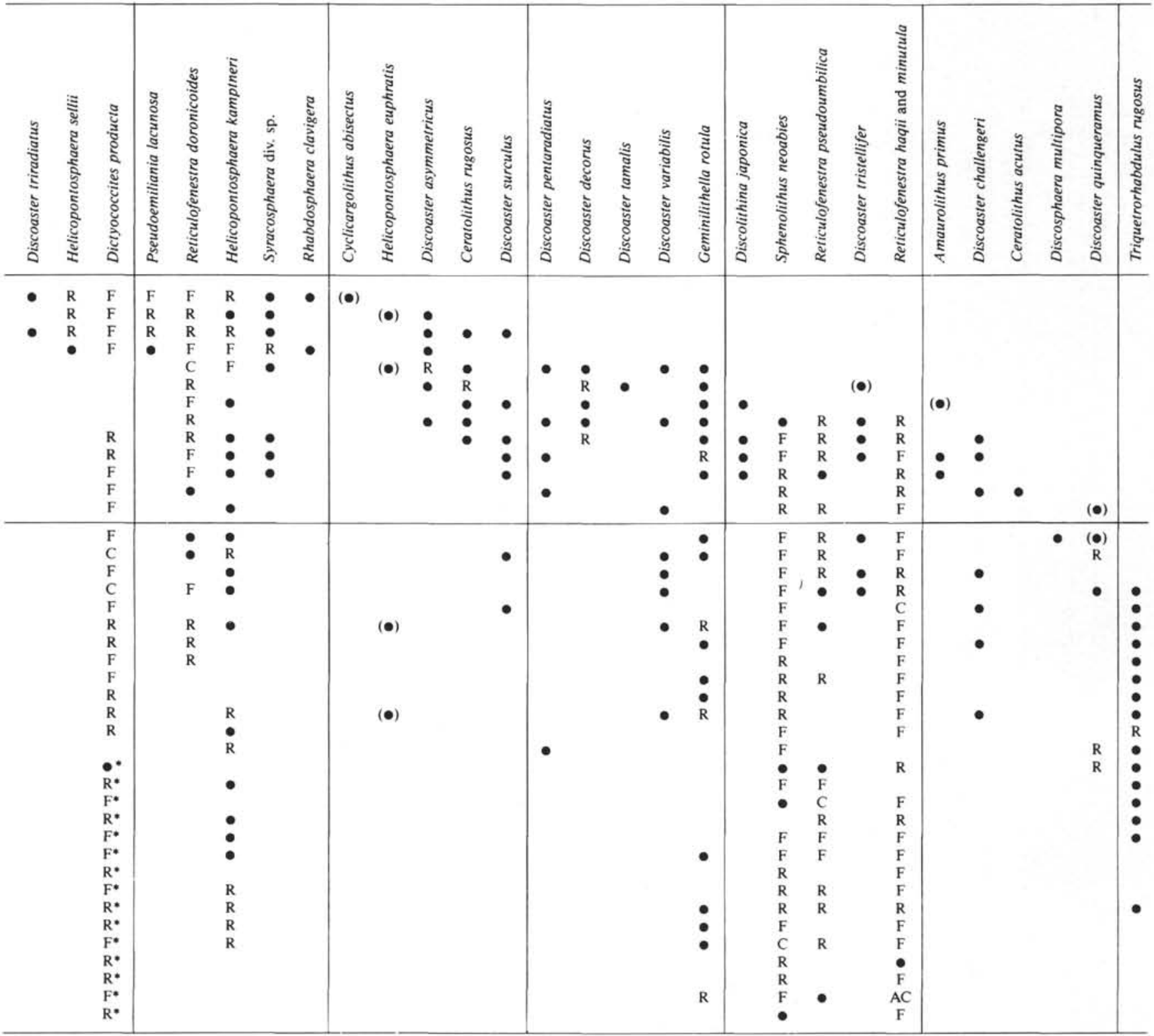

Almost all the zones from the zonation of Bukry (1973a) can be found at Site 574. On the basis of the sedimentation rates, the stratigraphic column can be divided into four parts:

1. From the top of the Pliocene to the section at about $10.6 \mathrm{Ma}$, the rate is low. Most of the zones are represented by very few samples, and the scarcity of nannofossils and the low specific diversity do not facilitate the biostratigraphy. It is interesting to note the presence of $D$. tristellifer, which Bukry (1981) considers to be a warm water species of the lower Pliocene. At Site 572, it is present in the Ceratolithus acutus Subzone and in the $C$. rugosus Subzone, which agrees with Bukry's assignment. But in the Reticulofenestra pseudoumbilica zone and in the $D$. tamalis Subzone, some specimens are attributable to "Catinaster mexicanus" Bukry. This " $\mathrm{Ca}$ tinaster" has a morphology similar to that of the knobbed center of $D$. tristellifer. There could also be some reworked and dissolved specimens of $D$. tristellifer present, so in the present study the two "taxa" are given under the same name.

2. Between about 10.6 and $13 \mathrm{Ma}$, there is an unconformity corresponding to the lower part of the $D$. bellus Subzone and to the D. hamatus Zone. An unconformity corresponding to this interval may also be present at Site 573.

3. Below this unconformity and down to the middle lower Oligocene, the rate of sedimentation appears to have been high, as it was at Site 573 for the same period. In the lower to middle Miocene section, Sphenolithus moriformis specimens are usually abundant and are commonly in the form of large sphenoliths, whereas at Site 574 they are rare and most of them are small. S. heteromorphus is also very rare in its nominate Zone CN4, 
Table 2. (Continued).

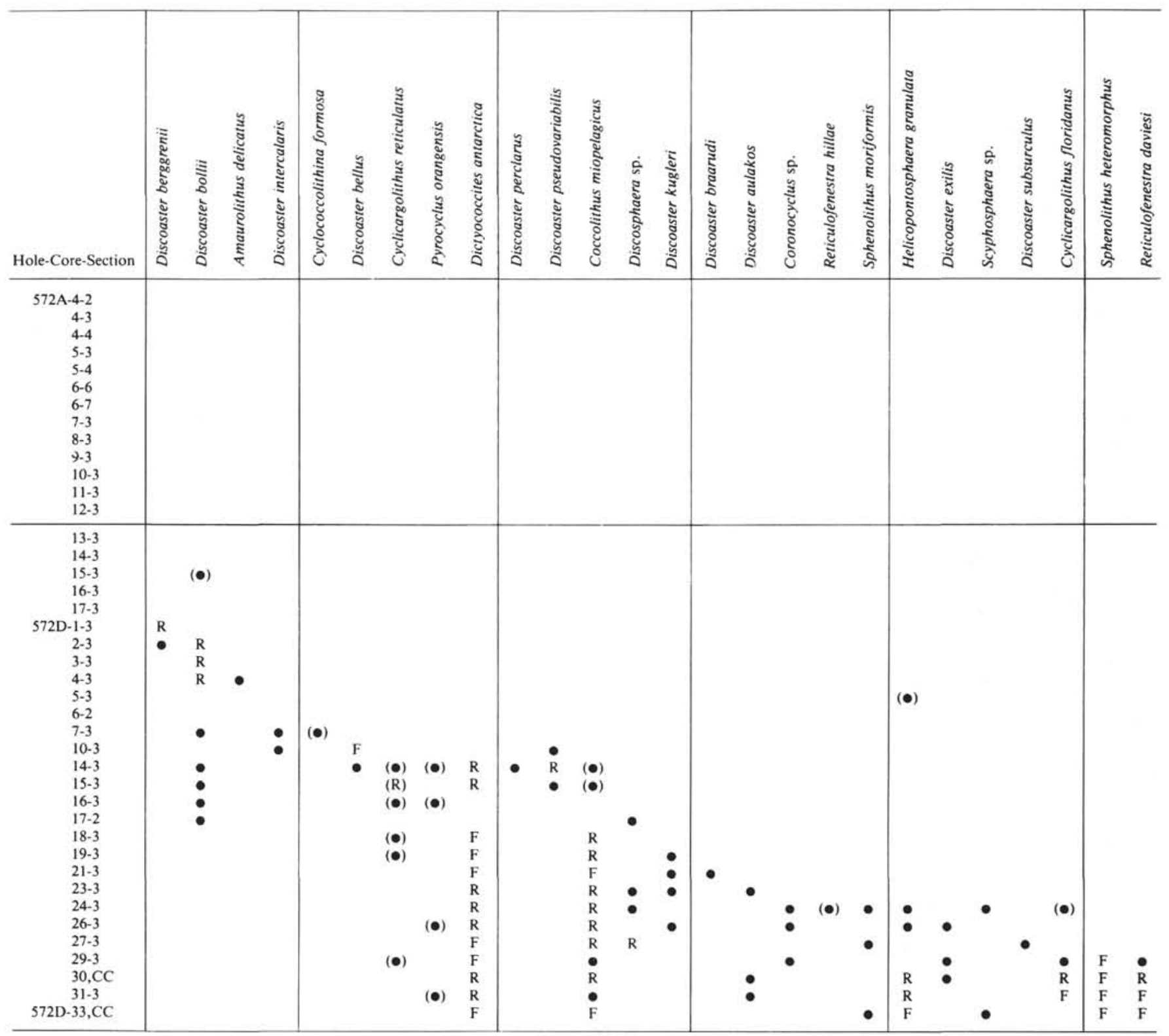

while $S$. conicus (which is almost absent at the other sites) is common. In the same interval Coccolithus pelagicus is abundant; the presence of this cool water species may explain the absence of warm water sphenoliths.

4. The lowermost Oligocene section below $34 \mathrm{Ma}$ is very thick; it begins with a thin Coccolithus formosus Subzone. The deepest sediments at Hole 574C are attributable to the Eocene Discoaster barbadiensis Zone according to the presence of poorly preserved $D$. saipanensis, alone or with $D$. barbadiensis. Between the Oligocene and the Eocene sections there are metalliferous sediments. At Site 573, the metalliferous sediments are completely barren of nannofossils. At Site 574 , some very rare and poorly preserved specimens of $D$. saipanensis were found at just below the Oligocene boundary $(574 \mathrm{C}-35-5,5 \mathrm{~cm})$. This observation allowed me to place the Eocene/Oligocene boundary between 504.14 and
$504.55 \mathrm{~m}$, in the upper part of the metalliferous sediments. This succession can be schematized as follows:

\begin{tabular}{|c|c|c|}
\hline $574 C-33-4,114 \mathrm{~cm}$ & No D. saipanensis & $\begin{array}{l}\text { Subzone } \\
\text { CP16b } \\
\text { Oligocene }\end{array}$ \\
\hline $\begin{array}{l}574 C-33-5,5 \mathrm{~cm} \\
574 C-33-5,47 \mathrm{~cm} \\
574 \mathrm{C}-33-5,65 \mathrm{~cm} \\
574 \mathrm{C}-34-1,120 \mathrm{~cm}\end{array}$ & $\begin{array}{lr}\text { Scarce D. saipanensis } & \text { Metalliferous } \\
\text { sediment } & \\
\text { No D. saipanensis } & \end{array}$ & $\begin{array}{l}\text { Zone CP15? } \\
\text { Eocene? }\end{array}$ \\
\hline $\begin{array}{l}574 \mathrm{C}-34-2,6 \mathrm{~cm} \\
547 \mathrm{C}-34-2,60 \mathrm{~cm}\end{array}$ & D. saipanensis & \multirow{2}{*}{$\begin{array}{l}\text { Zone CP15 } \\
\text { Eocene }\end{array}$} \\
\hline $\begin{array}{l}574 C-34-2,93 \mathrm{~cm} \\
574 C-35, C C\end{array}$ & $\begin{array}{l}\text { D. saipanensis and } \\
\text { D. barbadiensis }\end{array}$ & \\
\hline
\end{tabular}

As at Site 573, the Eocene/Oligocene boundary occurs in the barren metalliferous sediment. The succes- 
CENOZOIC NANNOFOSSILS, LEG 85

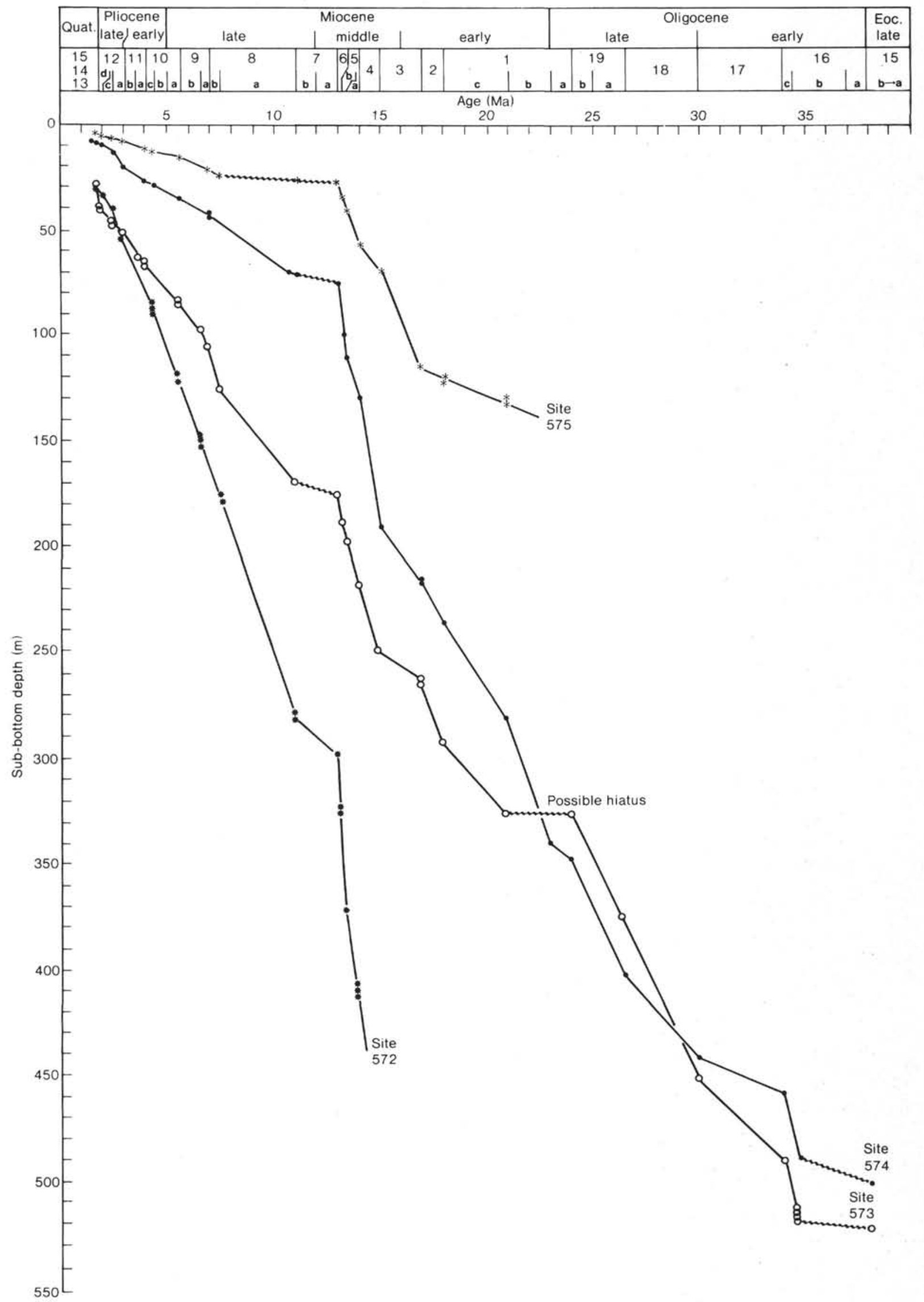

Figure 3. Rate of sedimentation at the four sites using ages estimated from Bukry's zonation (Okada and Bukry, 1980). 
Table 3. Occurrence and estimated abundance of nannofossils in selected samples from Site 573. Symbols same as for Table 2.

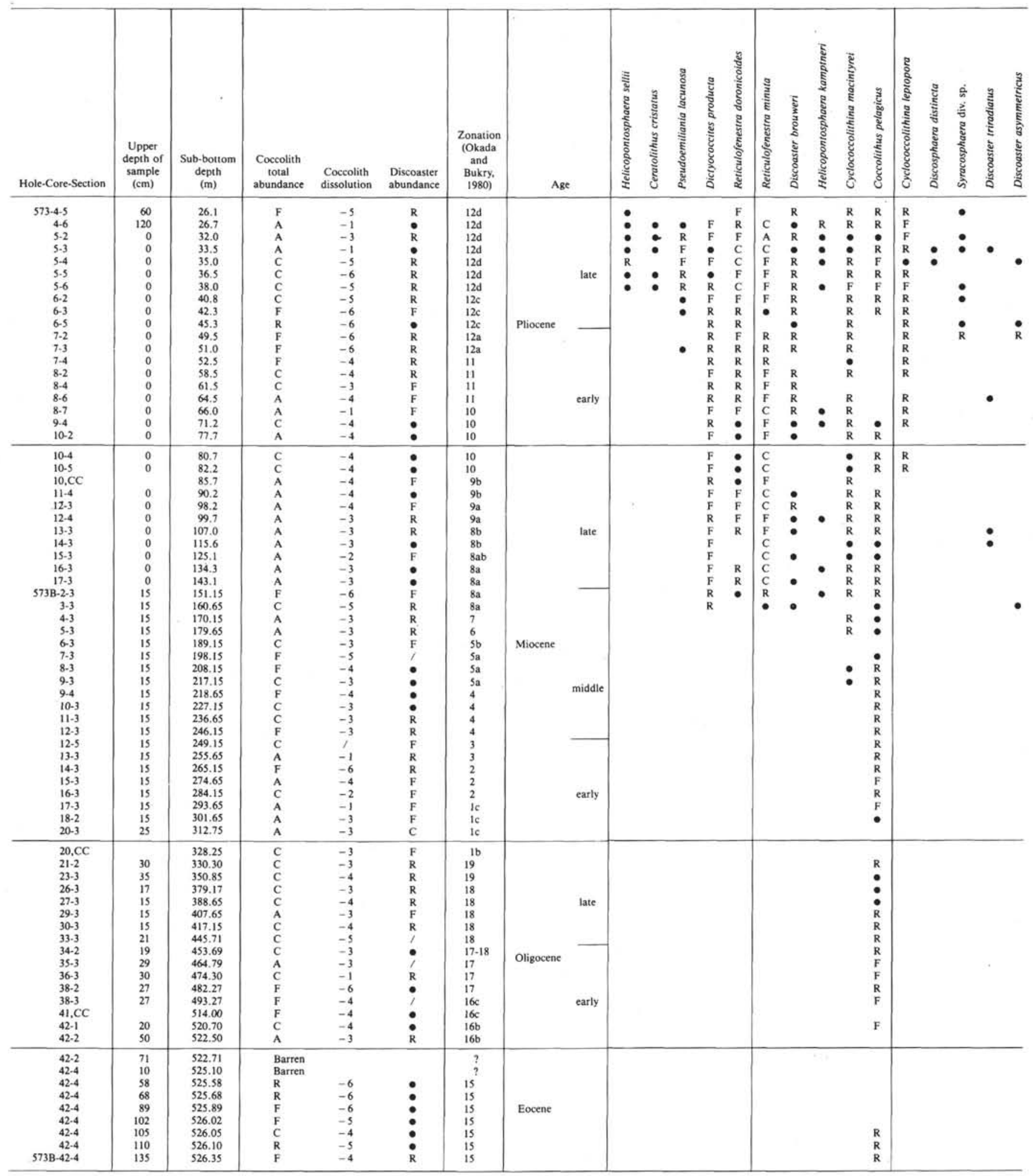

sion at Site 574 is very similar to that at Site 573 , but here nannofossils were present in all the samples taken from the metalliferous sediments, allowing the identification of the precise Eocene/Oligocene boundary. The presence and age of the metalliferous sediments are the same at Sites 573 and 574; at both sites they are overlain by sediments of Subzone CP16b and underlain by Zone CP15.

Site $\mathbf{5 7 5}$

Site 575 (Table 5 and Fig. 3) was cored on the northern flank of the equatorial high-productivity zone $\left(05^{\circ}\right.$ 
Table 3. (Continued).

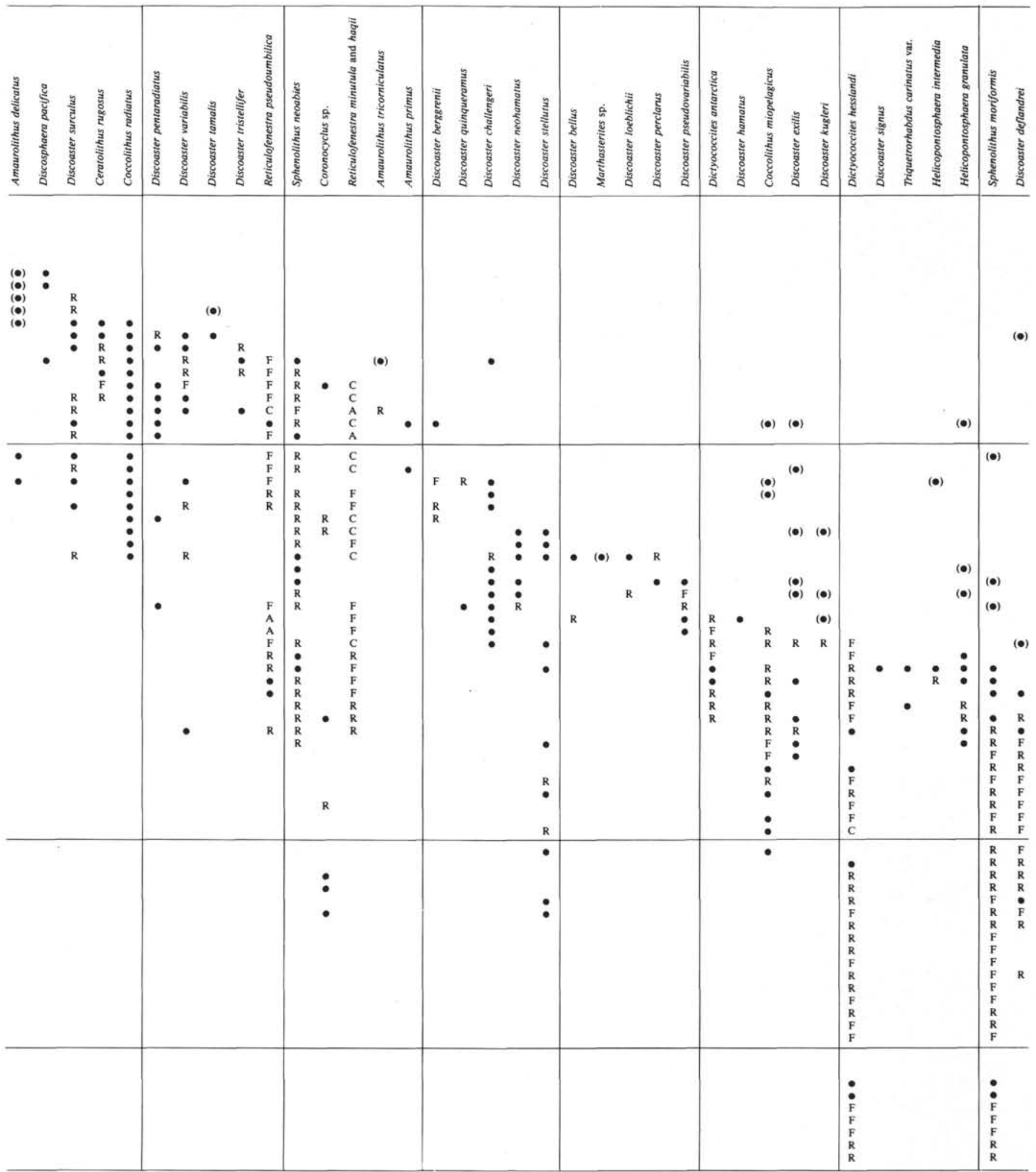

$51.00^{\prime} \mathrm{N}, 135^{\circ} 02.16^{\prime} \mathrm{W} ; 4536 \mathrm{~m}$ sub-bottom) in the vicinity of the Clipperton Fracture Zone. Four holes were drilled; 60 cores were recovered. The basement was not reached. Site 575 presents an almost continuous succession from the lowermost Miocene to the upper Pliocene.
Nannofossils were studied in Holes 575 and 575A. Coccoliths fluctuate in abundance between abundant and rare in the Miocene; they are usually scarce in the Pliocene. The degree of dissolution also fluctuates (from strong to weak) up through lower middle Miocene. In 
Table 3. (Continued).

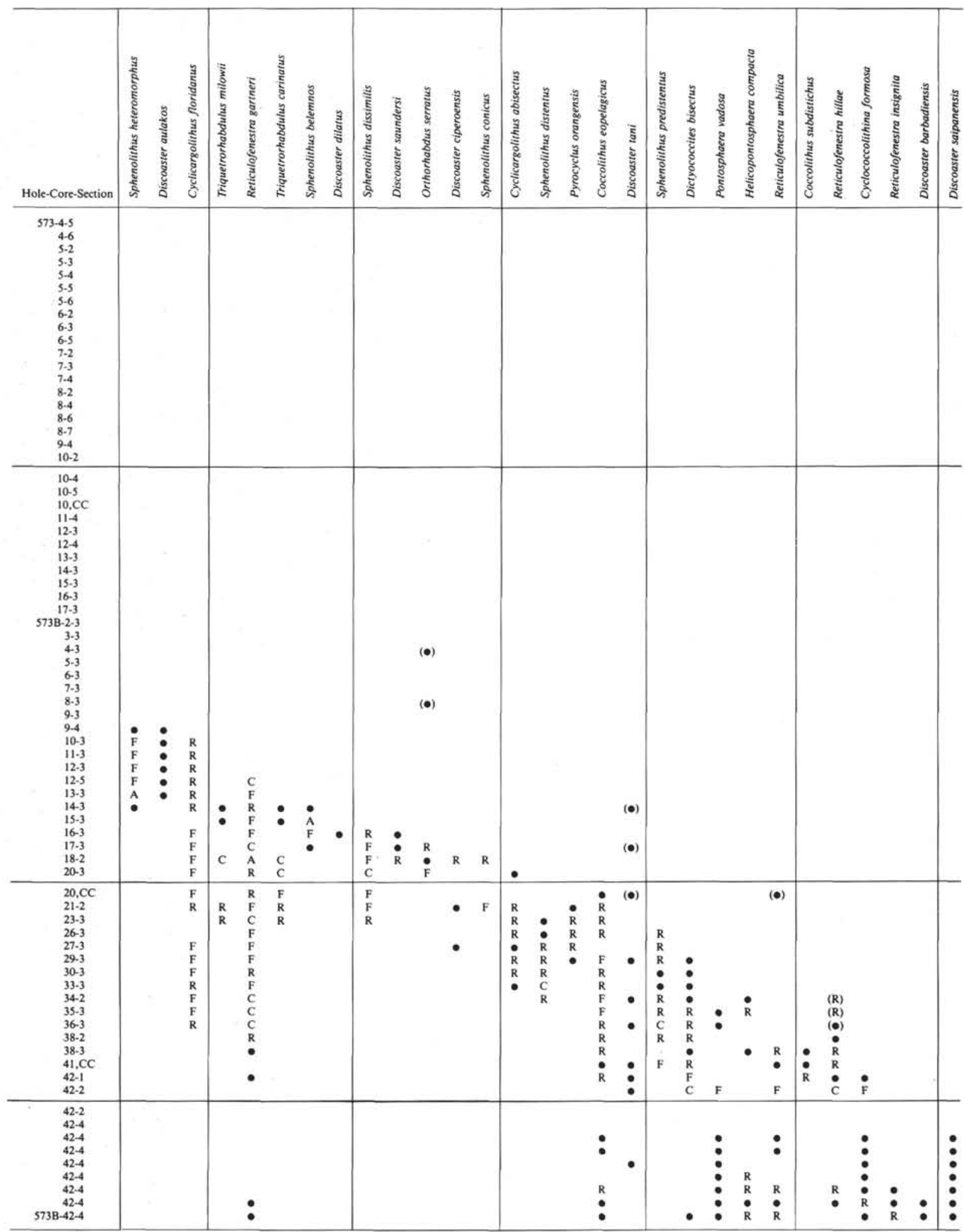

the section representing the past $13 \mathrm{Ma}$, cycles of dissolution correspond to various environmental changes. Discoasters are usually rare except for some short acme periods: Discoaster variabilis at the top of the Helicopontosphaera ampliaperta Zone, D. surculus in the
Amaurolithus tricorniculatus Zone, $D$. berggrenii in the Reticulofenestra pseudoumbilica Zone, and D. loeblichii in the $D$. quinqueranus Zone.

Reworking is significant throughout Site 575; reworked Eocene-Pliocene specimens are mixed with in situ as- 
semblages at almost all levels. This continuous reworking and the thick sections showing dissolution characterize the sediments at Site $\mathbf{5 7 5 .}$

The Plio-Pleistocene boundary occurs within a section in which nannofossils are strongly dissolved (see the Quaternary study by Pujos, this volume), but at 575$1-3,140-141 \mathrm{~cm}$, the assemblage is characteristic of the Cyclococcolithus macintyrei Subzone, which corresponds to the uppermost Pliocene. (1) From the latest Pliocene to middle late Miocene (D. neohamatus Zone), the sedimentation rate appears to have been low. From about 7.5 to $13 \mathrm{Ma}$, there was apparently almost no sedimentation. This interval may correspond to the hiatus found at Sites 573 and 574, but it is even longer here at Site 575 than at the previous two sites. The low sedimentation rate may have resulted from an intensification of the currents in this area, which is evidenced by the extent of reworking at this site. (2) In middle and late early Miocene, the rate of sedimentation apparently increased considerably and was about the same as at the other sites. All the corresponding zones are well represented. (3) In the early Miocene, the rate of sedimentation appears to have dropped to as low as it was in the upper part of the section at this site. The oldest nannofossils recovered here belong to the $D$. deflandrei Subzone.

\section{TAXONOMIC NOTES ON SOME SPECIES}

\section{Small- and Medium-Sized Reticulofenestra and Dictyococcites}

Reticulofenestra and Dictyococcites are two genera that, according to Hay (1977), belong to the family of Gephyrocapsaceae, along with the genera Gephyrocapsa, Pseudoemiliania, Emiliania, and others. Reticulofenestra and Dictyococcites resemble one another closely. The main difference in the construction of their coccoliths is that Dictyococcites has its center spanned by a grid. Its form is that of a completely closed or slitted central area when observed under crossed nicols. In contrast, coccoliths of Reticulofenestra have an open central area, which may be spanned by a reticulated grid. Elements of the grid are independent of those of the shields, and between crossed nicols there is usually a dark empty space in the center of the coccolith or a thin structure that is not easy to distinguish.

Thus, the difference between these two genera can be described as being between a "closed" (Dictyococcites) and an "open" variety (Reticulofenestra). It is the same kind of characteristic that is used to distinguish the closed and open forms of Gephyrocapsa from the Quaternary (Pujos, this volume). In fact, it can be considered the same problem: the late Pliocene Dictyococcites or Reticulofenestra may be the ancestor of Gephyrocap$s a$. For example, it is not easy to separate $R$. minuta from $G$. aperta, especially when the cross-bar of $G$. aperta is dissolved. The problem of " $R$." tagana will be discussed below; its small coccoliths have a cross-bar, usually a characteristic element of the genus Gephyrocapsa. D. producta is also of the same lineage as G. producta. Some closed and very small placoliths were also found at Site 572. Under a light microscope, what looks like a cross-bar appears. These forms look like small specimens of $G$. sinuosa, although their taxonomy is not yet clear; SEM observation is necessary to further clarify the problem.

The largest species of Dictyococcites and Reticulofenestra, namely $D$. bisectus, $R$. hillae, and $R$. umbilica, are well documented and are used as stratigraphic markers for the Cenozoic. It is therefore unnecessary to discuss them here. Thus, only the small- and medium-sized specimens of these genera will be described in detail. These species are not well known; Haq (1968 and 1971) and Backman (1980) established distinctions between these small specimens ( $<11$ to $12 \mu \mathrm{m}$ in length).

\section{Reticulofenestra Species}

\section{Miocene-Pliocene Reticulofenestrids}

Miocene-Pliocene reticulofenestrids were studied in detail by Backman (1980); he accurately measured many specimens belonging to five species (Reticulofenestra gelida, $R$. haqii, $R$. minuta, $R$. minutula, and $R$. pseudoumbilica), and he used these measurements in various statistical methods. His purpose was to define the relationships and differences between these species more clearly. Backman concluded that it was possible to distinguish the various species by using some simple criteria: the length of the placolith along the long axis, and the relative size of the central opening to the overall size. Other more sophisticated criteria are less useful; for example, he found that the number of elements of the shields varies as a function of the increasing length of the coccoliths, and thus it was not necessary to count these elements. The study of this group is therefore possible only with light microscope observations. Most of the discriminating criteria are drawn in a simplified manner on Plate 1. The appearance of the coccoliths under crossed nicols is shown along with the silhouette (drawn to scale).

\section{Reticulofenestra minuta Roth, 1970 \\ (Plate 1, figs. 1a, b)}

This is the smallest species of the group. Its minute size and distribution make it difficult to separate this species from the smallest $\mathrm{Ge}$ phyrocapsa (especially $G$. aperta) of the lower Pleistocene. It appears at Leg 85 sites in the lower upper Miocene in the lower part of Zone $\mathrm{CN} 8 \mathrm{a}$, and it is common up to the very top of the Neogene. Nevertheless, it disappears in Subzone CN10c at Site 574 and is completely absent from Site 575 because of dissolution.

According to Haq (1976) this species is biogeographically important: it dominates nannofossil assemblages in the middle and high latitudes. However, $R$. minuta is often common in the equatorial area. $\mathrm{Ci}$ ta et al. (1978) found it as a dominant taxon in Miocene sediments of the western Mediterranean Sea.

Reticulofenestra minutula (Gartner) Haq and Berggren, 1978, and R. haqii Backman, 1978

(Plate 1, figs. 2a, b and 3a, b)

Usually in the literature, these two species are grouped and named together as small Reticulofenestra pseudoumbilica. It is true that the two species are very difficult to distinguish from one other. In his biometrical study, Backman (1980) grouped them and concluded that the only difference was the slightly larger central opening of $R$. minutula, which could be an environmental (latitudinal) effect. $R$. minutula and 
Table 4. Occurrence and estimated abundance of nannofossils in selected samples from Site 574. Symbols same as for Table 2.

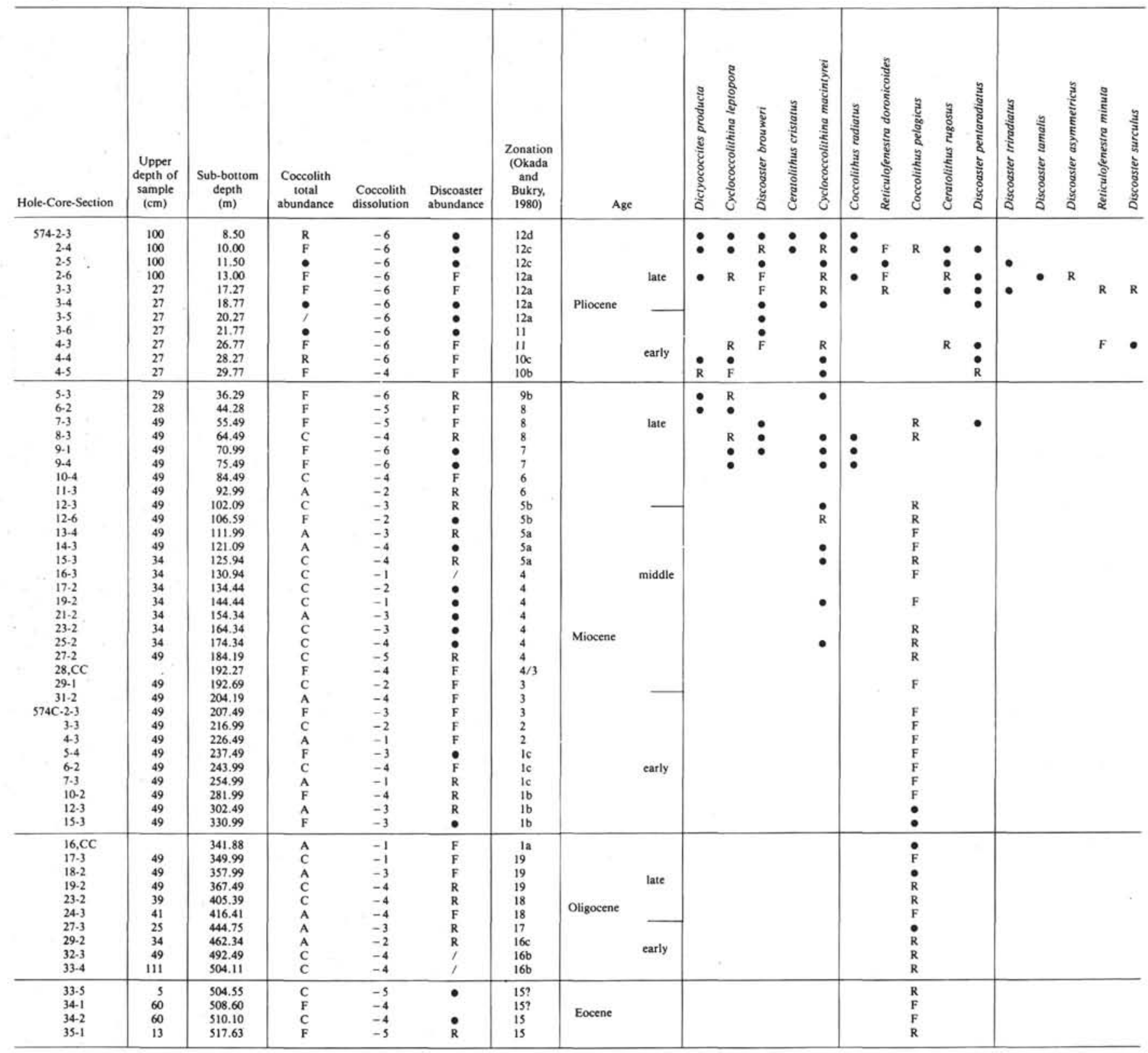

$R$. haqii are grouped together in the present study. They occur at all sites in the interval between lower middle Miocene (lower part of Zone $\mathrm{CN} 4$ ) and lower Pliocene (Zones CN10c or CN11).

Some authors (Roth, 1973; Backman, 1980) place R. doronicoides in the synonymy of $R$. minutula, but the two species can be easily distinguished even with a light microscope. $R$. doronicoides is clearly larger and has a less open central area than $R$. minutula and $R$. haqii.

Reticulofenestra doronicoides (Black and Barnes) n. comb. (Plate 1, figs. 7a, b)

Backman (1980) placed the species doronicoides in the genus Dictyococcites; I do not agree with this assignment because of the open central area of the coccoliths. Roth (1973) combined this species into Crenalithus, but as does Backman (1980), I consider Crenalithus to be a junior synonym of Reticulofenestra.

$R$. doronicoides is often confused with $R$. minutula (see above), but they can easily be distinguished by comparing their dimensions. $R$. doronicoides is present at all sites of Leg 85 except Site 575. Its ab- sence at the latter site is probably due to strong dissolution. At Site 574 it first appears in Subzone CN12a (middle Pliocene), and at Sites 572 and 573 it starts appearing in Zone CN8 (upper Miocene). When present, this species ranges up into the uppermost Pliocene.

\section{“Reticulofenestra" tagana (Fonseca) n. comb.} (Plate 1, figs. 4a, b)

Assigned as a species of Coccolithus by Fonseca (1976) in the Atlantic Ocean, this species was renamed as a species of Crenalithus by Bukry (1981) in his study of the Pacific coast of Mexico and California. Backman (1980) considers Crenalithus to be a junior synonym of Reticulofenestra. It is problematic to place this species within the genus Reticulofenestra, because " $R$." tagana has a notable cross-bar that is a characteristic feature of the genus Gephyrocapsa. This problem is the same as for some other "Reticulofenestra" ( $R$. doronicoides) and for some "Dictyococcites" (D. producta).

" $R$." tagana was found at Site 572 only from the lowest part of the section (Zone CN4) up to the upper Pliocene (Zone CN12); in this in- 
Table 4. (Continued).

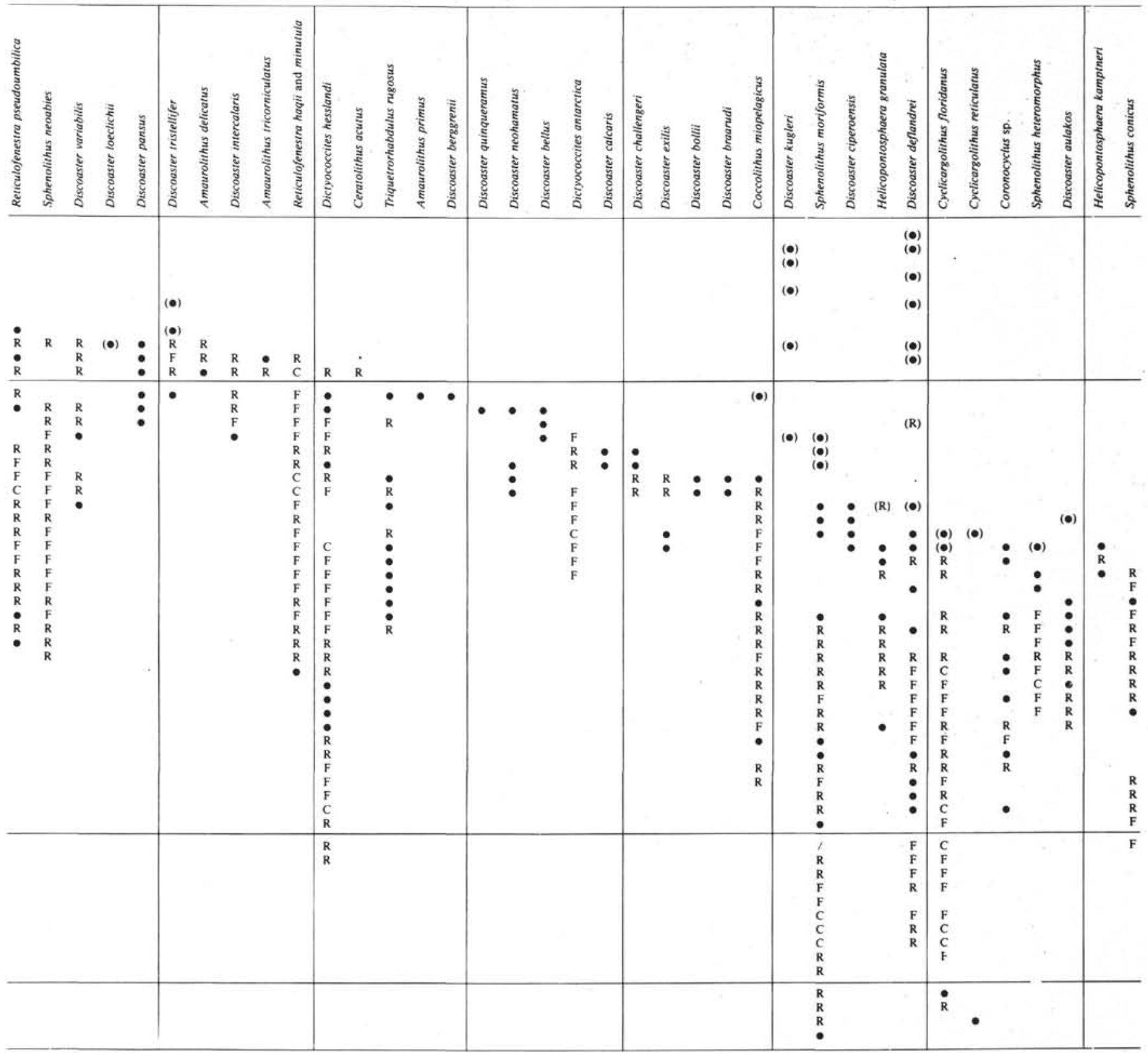

terval it is often abundant. " $R$." tagana has been reported mainly from Portugal and from sediments recovered during Leg 63; in these two areas upwelling is common.

" $R$. tagana" coexists with abundant small coccoliths having closed central areas and cross-bars. This species can be placed between typical small Reticulofenestra and " $R$. tagana;" it is very similar to the small type of the Quaternary Gephyrocapsa sinuosa. For Leg 85, the two taxa are put under the same name of " $R$." tagana. A further detailed study might resolve the ambiguity.

\section{Reticulofenestra gelida (Geitzenauer) Backman, 1978, and Reticulofenestra pseudoumbilica (Gartner) Gartner, 1969 (Plate 1, figs. 5a, b and 6a, b)}

According to Backman, it is not possible to separate these two species by biometry: Reticulofenestra gelida could be the winter ecotype of $R$. pseudoumbilica. Lohmann and Carlson (1981) also group these two taxa "to minimize taxonomic problems," and they conclude that together the two taxa could be indicative of cooler waters, especially when they are associated with Coccolithus pelagicus (which is usually the case). In the present study, the two species are not distinguished from one other, and the group is named $R$. pseudoumbilica. Abundant at all the sites, they appear in the lower middle Miocene (Zone CN4) and become extinct in the upper lower Pliocene (Zone CN11). This taxon is usually absent between Zones CN8 and CN10b, which is consistent with its usual appearance in tropical and equatorial areas (Bukry, 1972; 1973a,b).

\section{Eocene-Oligocene Reticulofenestrids}

Eocene-Oligocene reticulofenestrids were not studied by Backman (1980). In his detailed low-latitude zonation, Bukry (1973a) used $R$. gartneri for a common medium-sized placolith. A larger and a smaller form are 
Table 4. (Continued).

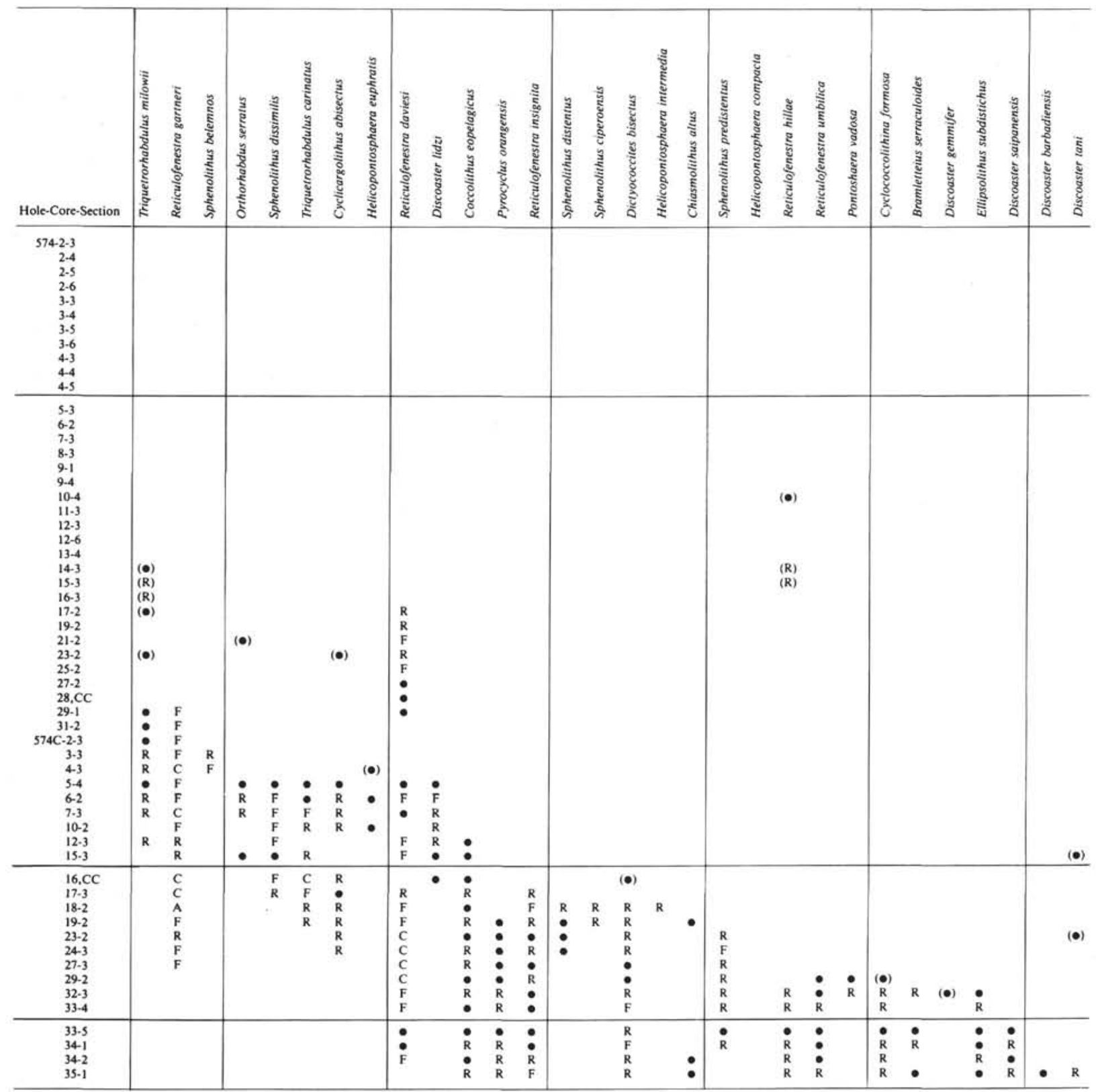

observed in the Paleogene sediments at Leg 85 and are identified as $R$. daviesi and $R$. insignita, respectively.

Reticulofenestra insignita Roth and Hay, 1967 (Plate 1, figs. 8a, b)

This small species was found for the first time in the Reticulofenestra laevis Zone of the Blake Plateau. Some dissolved specimens are present between Zones CP15 and CP19 at Site 574 and only in the uppermost Eocene sediments (Zone CP15b) at Site 573.

Reticulofenestra gartneri Roth and Hay, 1967

(Plate 1, figs. 9a, b)

This marker species has been found at low latitudes by Bukry (1973a) and on Leg 85 between the middle Oligocene (Zones CP17 or $\mathrm{CP} 18$ ) and the upper lower Miocene (Zones $\mathrm{CN} 2$ or CN3). It is present only in Subzone CN1c at Site 575, which may be due to some special environment. Because of its morphology and distribution, $R$. gartneri may be considered a possible ancestor of $R$. pseudoumbilica.

\section{Reticulofenestra daviesi (Haq) Haq, 1971}

(Plate 1, figs. 10a, b)

This species was combined into Dictyococcites by Perch-Nielsen (1971); Haq (1971) transferred it to Reticulofenestra. But it is obvious that there is an ambiguity in its generic attribution, which may be why $I$ confused it with $D$. hesslandi (see below). $R$. daviesi is present at the Eocene/Oligocene boundary (Zones CP15/CP16), and it persists perhaps up into the lower Miocene.

\section{Dictyococcites Species}

\section{Miocene-Pliocene Dictyococcites Species}

The only Dictyococcites found in the upper Miocene to Pliocene is $D$. producta. 
Dictyococcites producta (Kamptner) Backman, 1980

(Plate 1, figs. 13a, b)

The problem of the generic attribution of the species producta was explained above. It is obvious that the same species is present in the Cenozoic and Quaternary. But in the Neogene specimens, the crossbar (which is common in the Pleistocene forms) seems to be absent. Therefore, it is necessary to use the generic name Dictyococcites. This taxonomic problem will be described in detail in a future study of the Neogene and lower Pleistocene assemblages.

$D$. producta is the smallest Dictyococcites described for Leg 85 . Its placoliths are always smaller than $4.5 \mu \mathrm{m}$ in length. As is true for $R$. doronicoides, $D$. producta is absent from Site 575. It appears in Zone CN8 and persists up to the Quaternary at other sites.

\section{Oligocene-Miocene Dictyococcites Species}

The Oligocene-Miocene Dictyococcites are represented by the $D$. antarctica-hesslandi complex. Backman (1980) notes that there is a gradation in the measured parameters of the placoliths of these two species from Miocene to Pliocene; thus, it could be difficult to separate them. Nevertheless, a characteristic extinction figure, a notable difference in size, and a different distribution usually make their distinction easy (see Plate 1 and discussion below).

\section{Dictyococcites antarctica Haq, 1976}

(Plate 1, figs. 12a, b)

D. antarctica may be the ancestor of D. producta. Backman (1980) showed the continuous evolution from $D$. antarctica (medium-sized placoliths of the middle lower Miocene) to $D$. producta (small-sized placoliths of the Pliocene). As for R. minutula-haqii, the distinction from $D$. hesslandi is easy (see Plate 1): placoliths of $D$. antarctica are longer than $4 \mu \mathrm{m}$. It is present between Zones $\mathrm{CN} 3 / 4$ and $\mathrm{CN} 8$ (middle Miocene) at all Leg 85 sites except Site 575, where it was not found.

\section{Dictyococcites hesslandi (Haq) Haq and Lohmann, 1976} (Plate 1, figs. 11a, b)

Dictyococcites hesslandi is the senior synonym of D. scrippsae Bukry, which is a marker species at low latitudes (Bukry, 1973a). According to Backman (1980), it is possible to follow the evolution of this taxon through the Miocene using the length of its placoliths: 3 to $5 \mu \mathrm{m}$ long in lower Miocene sections and 3 to $8 \mu \mathrm{m}$ long in upper lower Miocene.

This morphologic instability and severe dissolution at some sites may explain why it was not possible to separate $D$. hesslandi from $R$. daviesi. It seems wiser to group these two taxa together to avoid stratigraphic problems. $D$. hesslandi and $R$. daviesi are already present at the Eocene/Oligocene boundary (Zones CP15 or CP16) and persist up through lower middle Miocene (Zones CN4/5). At Site 574, there are some morphologic variations within the $D$. hesslandi-daviesi group: open coccoliths $(R$. daviesi ?) are predominant from Zone CP15 to $C N 1 c$, and closed coccoliths ( $D$. hesslandi ?) are found from the upper part of Zone CP19 to Subzone CN10b. This observation, however, is tentative because of the influence of dissolution, which can remove the central area of the placoliths and transform a closed Dictyococcites into a form that resembles an open Reticulofenestra.

\section{Medium-Sized Five-Rayed Discoasters}

The group of five-rayed discoasters discussed here is restricted to a period younger than middle Miocene. Of course, prior to that time some five-rayed discoasters occurred, and some of them are marker species, such as D. hamatus, a large umbrella-like discoaster restricted to Zone CN7. Five species of Discoaster found in lower upper Miocene sediment are exclusively five-rayed. They succeed one another, and their distinction is not always easy. It is therefore necessary to document their mor- phologic differences and their stratigraphic ranges (Bukry, 1973a).

Discoaster pentaradiatus Tan Sin Hok, 1927

This is the largest species of the group (usually about 15 to $20 \mu \mathrm{m}$ long). It is characterized by a sharp bifurcation at the end of each ray and by each ray being a crystal of calcite. The discoaster is composed of five distinct crystals that do not become extinguished at the same time under crossed nichols, whereas most of the other discoasters are made of a single crystal. $D$. pentaradiatus is rare in Zone CN8a, and it is present between Subzones CN8b and CN12c.

\section{Discoaster asymmetricus Gartner, 1969}

This slender discoaster is characterized by unequal angles between some of its rays. In spite of this distinctive character, it can be confused with $D$. bellus. Bukry (1973a) reports that in his Zone CN8a, the first rare specimens of $D$. asymmetricus are perhaps variants of $D$. bellus, which then disappear in the next Zone (CN8b). Thus Bukry thinks that $D$. bellus could perhaps be the ancestor of $D$. asymmetricus. D. asymmetricus is 12 to $15 \mu \mathrm{m}$ in length, and it occurs from Zone CN8a to CN12d, being abundant in Zones CN11b and CN12a.

\section{Discoaster bellus-quinqueramus-berggrenii Group}

These species are very similar, and they can occur in the same samples.

D. bellus Bukry and Percival, 1971, occurs from Zone CN6 to CN8b. It is small to medium in size (6 to $11 \mu \mathrm{m}$ long). Rays are almost blunt and they are strong and slightly bulging. The central area has no distinctive structure. The species may be the ancestor of $D$. asymmetricus and $D$. quinqueramus.

D. quinqueramus Gartner, 1969, has a restricted occurrence, from Zone CN8b to CN9b. D. quintanus is a junior synonym. Its length is about $10 \mu \mathrm{m}$. It is close to $D$. bellus, but it has a small, rough knob in the central area. Its rays are strong at their base and sharp at their ends, with straight edges, and inter-rays are usually angular.

D. berggrenii Bukry, 1971, has the same occurrence as D. quinqueramus and becomes very abundant in some samples of Zone CN9a. Such erratic occurrence may reflect some special localized environment. It is a small species (no more than $10 \mu \mathrm{m}$ long) with short, blunt rays. The center is often large, sometimes appearing as a rough pentagonal plate with a big knob, and the inter-rays are so large that they seem to be bi-angular.

\section{TENTATIVE ECOLOGICAL INTERPRETATION}

Nannofossils are planktonic organisms and should be considered good indicators of climatic and hydrologic changes. Some authors have tried to understand fluctuations in recent and living nannoplankton ecologically (Geitzenauer et al., 1977; Okada et al., 1977; Lohmann et al., 1981; Roth et al., 1982). The results are often disappointing, because quantitative relations could not be observed between species abundance and common parameters, such as surface temperature and salinity, in the same way as they can be for planktonic foraminifers. As a consequence, their usefulness for precise Cenozoic ecological interpretation is a priori questionable.

Nevertheless, nannofossil assemblages in Pacific oceanic sediments can be used for global estimates of environment. Dissolution and total abundance of coccoliths can reflect hydrology and climate, especially in the highproductivity areas. Bukry (in his various DSDP papers, particularly those for Leg 63,1981 ) used the following nannofossil criteria for ecological interpretation: Discoaster/Coccolithus ratio (which cannot be used for Leg 85 because of the scarcity of discoasters); the presence of some warm water or cool water discoasters; and the abundance of Coccolithus pelagicus and Cyclococco- 


\section{A. PUJOS}

Table 5. Occurrence and estimated abundance of nannofossils in selected samples from Site 575. Symbols same as for Table 2.

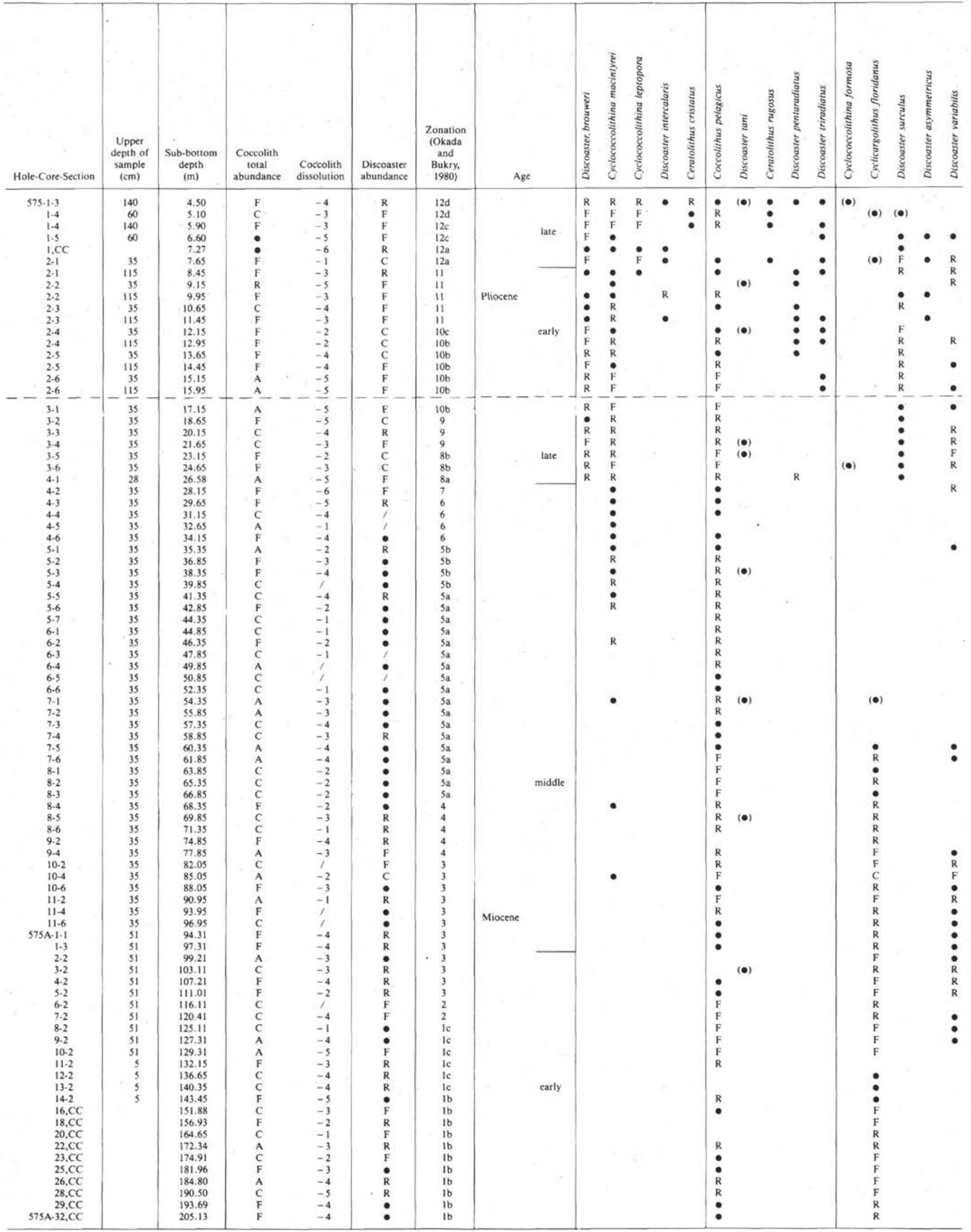


Table 5. (Continued).

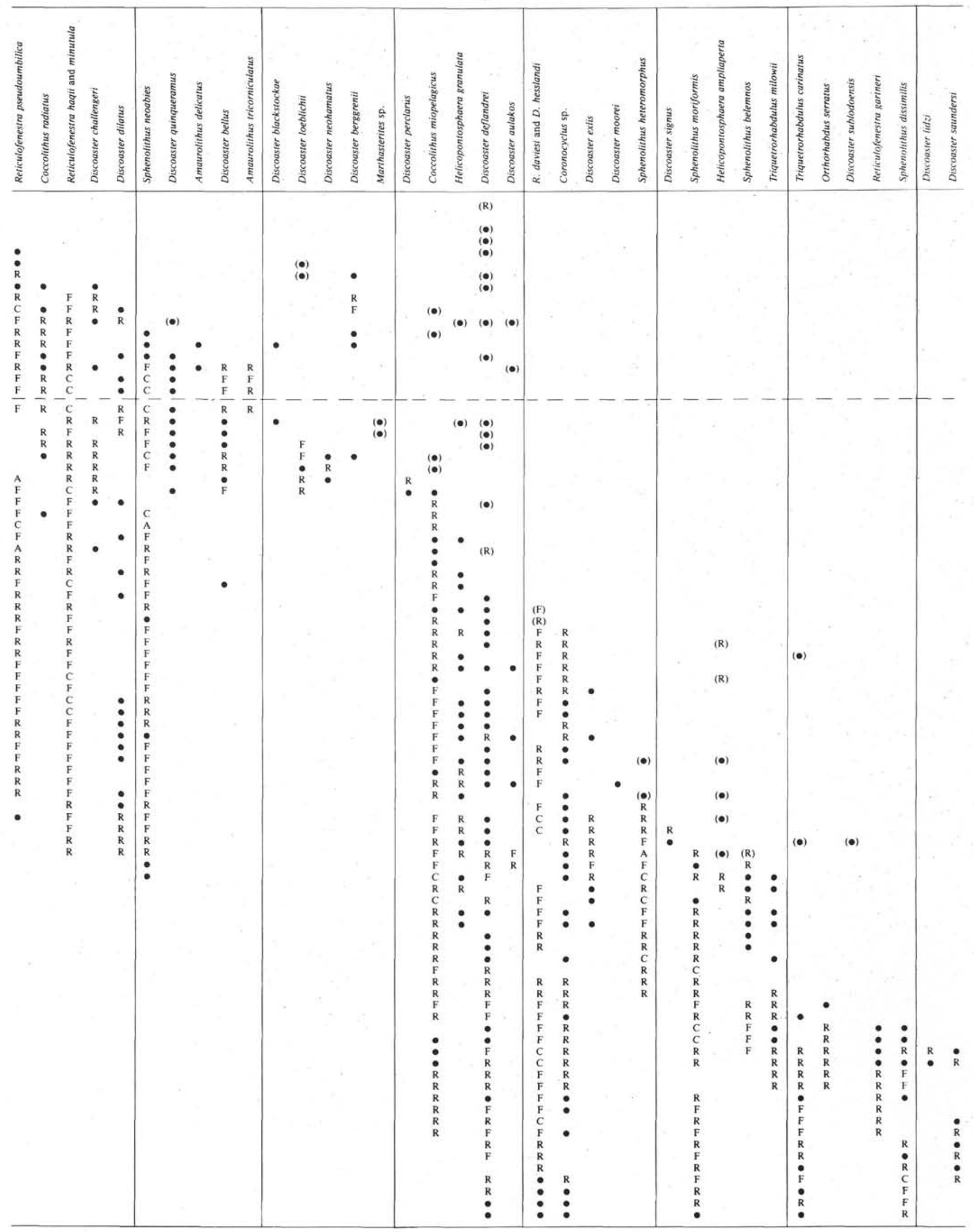


Table 5. (Continued).

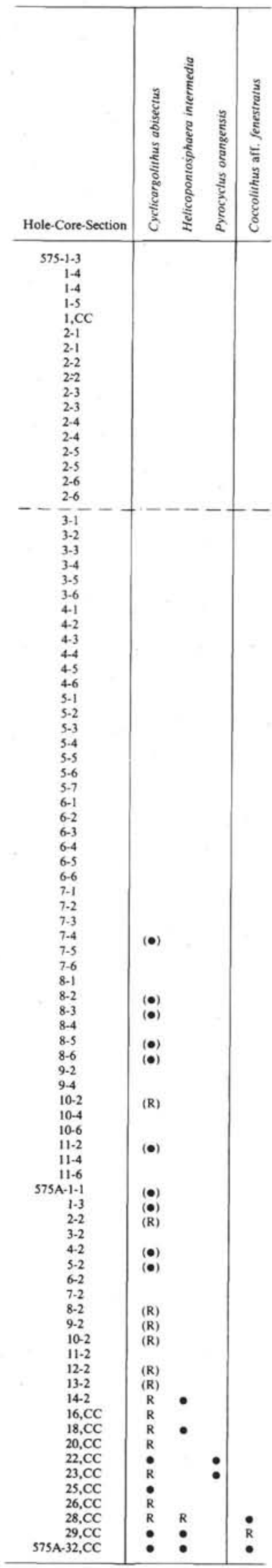

iithina div. sp. (which are both solution resistant, Cyclococcolithina more so than Coccolithus pelagicus). Furthermore, $C$. pelagicus is usually taken as a good index of cool water, even in pre-Quaternary sediments (Lohmann and Carlson, 1981).

Various aspects of the occurrence of nannofossils are presented in Figure 4, which also shows some geologic features such as unconformities or periods of low sedimentation rate and periods of equator crossing.

\section{Stratigraphic Unconformities}

Detailed descriptions of hiatuses or periods of reduced sedimentation are presented in Barron et al. (this volume). These intervals were recognized as changes in sedimentation rate (Fig. 2). Two of these changes were observed at Sites 573 and 574 (Eocene/Oligocene boundary and Oligocene/Miocene boundary), and another (middle upper Miocene) was recognized at four sites.

1. The Eocene/Oligocene boundary represents a time of global climatic cooling (Kennett et al., 1975) and is the beginning of modern climate. A world-wide Oligocene unconformity at the Eocene/Oligocene boundary was apparently caused by the increase in bottom water circulation at the onset of Antarctic glaciation. This bottom water was formed by the sinking of cold, dense surface water in Antarctic coastal regions; its temperature is estimated to have been 0 to $3^{\circ} \mathrm{C}$ (Woodruff et al., 1981; Keigwin and Keller, in press; Miller and Thomas, this volume).

A hiatus corresponding to a few meters of barren metalliferous sediment occurs at Sites 573 and 574 at the Eocene/Oligocene boundary. Most of the upper Eocene is present, and the hiatus seems to have begun in the latest Eocene at about 38-38.5 Ma. The oldest Oligocene nannofossil assemblages correspond to the upper part of Subzone CP16b at about $34.5 \mathrm{Ma}$. This hiatus is thus attributed to the beginning of the Antarctic glaciation.

2. At the Oligocene/Miocene boundary at Site 573 there is a hiatus representing a time period from 24 to 21 $\mathrm{Ma}$. The phenomenon is less significant at Site 574 where there is only a decrease in the sedimentation rate (and not a true hiatus) of much shorter duration (between 24 and $23 \mathrm{Ma}$ ). Thus, the beginning of the period of slow sedimentation is synchronous at both sites, but the phenomenon lasted longer at Site 573 than at Site 574.

This hiatus is a widespread phenomenon in the Pacific (Keller and Barron, 1982) and also at many places in the Southern Ocean. Kennett et al. (1975) assume that the opening of the deep Drake Passage occurred between 25 and $22 \mathrm{Ma}$. This event may have resulted in major climatic changes, which, in turn, may have caused the Oligocene/Miocene hiatus.

3. The third hiatus occurred in the middle-early late Miocene. According to Kennett et al. (1975), a major ice sheet developed on East Antarctica during this period (10 to $13 \mathrm{Ma}$ ). Woodruff et al. (1981) analyzed isotopic fluctuations of benthic foraminifers of the Miocene of the Ontong Java Plateau area. They concluded that during the early Miocene, polar glaciation was limited and deep water was warmer than it is today. Keller and Bar- 

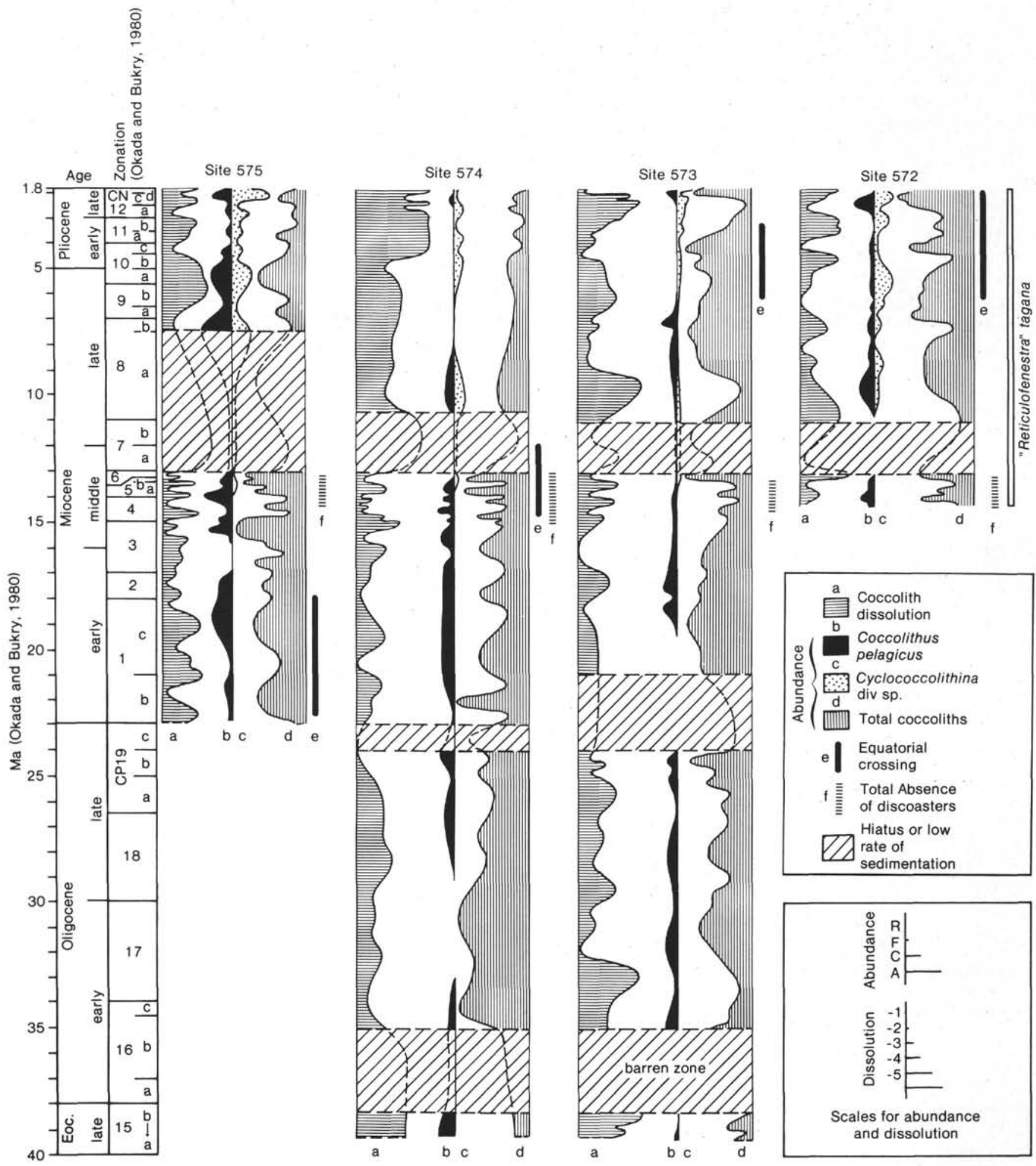

Figure 4. Tentative ecological scheme of the sequence at the four sites. The ecology is based on the following criteria: (a) the amount of coccolith dissolution, which is based on the nannofossil index of solution (see footnote to Table 2); (b) abundance of Coccolithus pelagicus; (c) abundance of Cyclococcolithina div. sp.; (d) total abundance of nannofossils (see footnote to Table 2); (e) times of equatorial crossings; and (f) total absence of discoasters.

ron (1982) argue that at the same time, there was an increase in the water mass stratification, which could strongly influence nannofossil distributions. In most of the lower Miocene cores of Leg 85, nannofossils are abundant and are not affected much by dissolution. This ob- servation seems to suggest a strong productivity without the existence of corrosive deep water.

The most important climatic change occurred in the middle Miocene between 16.5 and $13 \mathrm{Ma}$, which was "a transition from a relatively unglaciated world to one sim- 
ilar to today" (Woodruff et al., 1981). At this time, the Antarctic ice sheet was expanding and caused changes in oceanic circulation (Woodruff et al., 1981). This evolution occurred in three steps. (1) Between 16.5 and 14.8 $\mathrm{Ma}$, equatorial surface waters were warmer; nannofossils were abundant and dissolution was restricted at Sites 573 and 575 . (2) Woodruff et al. (1981) think that between 14.8 and $14.0 \mathrm{Ma}$, the Earth's climatic system became extremely unstable, oscillating between glacial and interglacial periods. Nannofossils recorded these climatic fluctuations at each site of Leg 85, especially discoasters, which disappeared almost completely during this period. Discoasters seem not to be able to withstand strong and rapid climatic variation caused by advances of glaciation. The same environmental change may have caused the definitive disappearance of this group in the early Pliocene. (3) After $14 \mathrm{Ma}$, the trend of glaciation was definitively established; this period corresponds to an unconformity and/or a period of a very low sedimentation rate at the Leg 85 sites. At Sites 572 and 573, the hiatus occurred between 13 and $11 \mathrm{Ma}$, whereas at Sites 574 and 575 it took place at $10.5 \mathrm{Ma}$ and 13 to 7.5 Ma, respectively. Like the Oligocene/Miocene hiatus, the arrival of Antarctic deep water was synchronous $(13 \mathrm{Ma})$ at all the sites, although it ended later toward the western direction. This can be interpreted either as an influence of the Antarctic Bottom Water (AABW) lasting longer in the area of Site 575 , or as a consequence of another phenomenon, such as an erosive current, at about $7.5 \mathrm{Ma}$.

\section{Equator Crossing}

It has been well documented that new crust generated at the East Pacific Rise moved from southeast to northwest (van Andel et al., 1975). All the Leg 85 sites crossed the equator during the Cenozoic at various times depending on their location (see site chapters, this volume): Site 572 from $\sim 6$ to $2 \mathrm{Ma}$; Site 573 from $\sim 6$ to $3.2 \mathrm{Ma}$; Site 574 from $\sim 14.6$ to $13 \mathrm{Ma}$; and Site 575 from $\sim 22.8$ to $18 \mathrm{Ma}$. The equatorial area of the middle and eastern Pacific Ocean is one of the most productive regions in the world because of the presence of warm water masses at the surface and diverging and converging subsurface currents.

Nannofossils observed in the Leg 85 cores seem to have been affected by this crossing of the equator. At each site, this event is marked by very high total abundance and fluctuating dissolution that indicates very high productivity. In this area of the Pacific, that very high productivity causes strong calcite dissolution due to the sinking of too much organic matter, which in turn creates corrosive bottom water due to oxidation of organic matter to $\mathrm{CO}_{2}$. Calcite skeletons tend to be dissolved. At these sites, nannofossil productivity is so high that, even with strong dissolution, many coccoliths remain in the sediment, although they become barely recognizable. This solution affects all nannofossils, even the most resistant ones such as Coccolithus pelagicus.

\section{Upwelling at Site $\mathbf{5 7 2}$}

Upwelling occurs often in high-productivity areas and is caused by the complex current system at the surface of the ocean. It is especially dominant in the eastern part of the area, where presently the Peru Current (in the southern part) and the California Current (in the northern part) are known to cause upwelling. Site 572 is located near the northeastern edge of the area in the vicinity of the Peru Current. Nannofossils are abundant during many time intervals at this site. Assemblages are strongly dominated by very small ellipsoidal placoliths that can be interpreted as being (1) indicative of cooler waters that are brought to the surface as upwelling waters and (2) characteristic of very strong upwelling, because most of these coccoliths are "Reticulofenestra" tagana and related forms. The species tagana was found in the Miocene of Portugal by Fonseca (1976) and in the Cenozoic off California by Bukry (1981). These two places are characterized by an almost permanent upwelling. Hence, the continuous presence of " $R$." tagana at Site 572 has been interpreted as the result of a permanent presence of upwelling waters in this area, at least since $14.5 \mathrm{Ma}$. " $R$." tagana was not found at the other sites of Leg 85, where upwelling was probably less frequent or nonexistent.

\section{Bottom Currents at Site $\mathbf{5 7 5}$}

Site 575 is characterized by several dissolution cycles and evidence of constant reworking. Furthermore, some marker reticulofenestrids are completely absent at this site; this absence is attributed to strong dissolution, rather than to ecological factors. These three phenomena (dissolution, reworking, and scarcity of reticulofenestrids) could be due to strong bottom currents of corrosive water that can rework nannofossils. It is well known that the Antarctic Bottom Water today flows over the area of present-day Site 575 (Wirrmann, 1980); it is likely that it has influenced the distribution of nannofossils at this site since early Miocene.

\section{Conclusions}

As explained at the beginning of this section, attempting to use nannofossils as ecological indicators can be disappointing. It was not possible to use them for temperature interpretation because (1) most of the cool water or warm water taxa used for such a purpose are solution prone, or else they are species of Discoaster, a group that is often scarce at Leg 85 sites; and (2) most of the published ecological studies deal only with the Neogene, which makes the interpretation of older assemblages difficult.

Nevertheless, nannofossils give us interesting information on the progression of Antarctic Deep Water in the central equatorial Pacific and hence on the development of Antarctic glaciation at three time periods during the Cenozoic. In addition, it is evident that the presence or absence of discoasters can be interpreted as the stability or unstability of global climate factors. "Reticulofenestra" tagana and related forms must be taken as indicators of prolonged upwelling; Site 572 is very likely located in an area of almost permanent upwelling. Site 575 is situated in an area where Antarctic Bottom Water persisted for a longer period during Antarctic glaciations. It is also apparent that the presence of a permanent Antarctic Bottom Water caused strong solution cy- 
cles and a constant and significant reworking at Site 575 since $22.5 \mathrm{Ma}$.

\section{REFERENCES}

Backman, J., 1980. Miocene-Pliocene nannofossils and sedimentation rates in the Hatton-Rockall Basin, NE Atlantic Ocean. Stockholm Contrib. Geol. 36.

Bukry, D., 1972. Coccolith stratigraphy, Leg 9, Deep Sea Drilling Project. In Hays, J. D., et al., Init. Repts. DSDP, 9: Washington (U.S. Govt. Printing Office), 817-832.

1973a. Low-latitude coccolith biostratigraphic zonation. In Edgar, N. T., Saunders, J. B., et al., Init. Repts. DSDP, 15: Washington (U.S. Govt. Printing Office), 685-703.

1973b. Coccolith stratigraphy, eastern equatorial Pacific, Leg 16, Deep Sea Drilling Project. In van Andel, T. H., Heath, G. R., et al., Init. Repts. DSDP, 16: Washington (U.S. Govt. Printing Office), 653-711.

1975. Coccolith and silicoflagellate stratigraphy, northwestern Pacific Ocean, Deep Sea Drilling Project, Leg 32. In Larson, R. L., Moberly, R., et al., Init. Repts. DSDP, 32: Washington (U.S. Govt. Printing Office), 677-701.

1981. Pacific coast coccolith stratigraphy between Point Conception and Cabo Corrientes, Deep Sea Drilling Project, Leg 63. In Yeats, R. S., Haq, B. U., et al., Init. Repts. DSDP, 63: Washington (U.S. Govt. Printing Office), 445-471.

Cita, M. B., Colalongo, M. L., d'Onofrio, S., Iaccarino, S., and Salvatorini, G., 1978. Biostratigraphy of Miocene deep sea sediments (Sites 372 and 375), with special reference to the Messinian/preMessinian interval. In Hsü, K. J., Montadert, L., et al., Init. Repts. DSDP, 42, Pt. 1: Washington (U.S. Govt. Printing Office), 671-708.

Fonseca, B., 1976. Coccolithus taganus, nouvelle espèce de coccolithophoridé du Miocène de Lisbonne. Bol. Soc. Geol. Portugal, 20:29-32.

Geitzenauer, K. R., Roche, M. B., and McIntyre, A., 1977. Coccolith biogeography from North Atlantic and Pacific surface sediments. A comparison of species distribution and abundances. In Ramsay, A. T. S. (Ed.), Oceanic Micropaleontology (Vol. 2): New York (Academic Press), pp. 973-1008.

Haq, B. U., 1968. Studies on upper Eocene calcareous nannoplankton from N.W. Germany. Stockholm Contrib. Geol., 18:13-74.

1971. Paleogene calcareous nannoflora. Parts I-IV. Stockholm Contrib. Geol., 25:1-158.

1976. Early Cenozoic nannoplankton biogeography of the Atlantic Ocean. Mar. Micropal., 1:119-194.

Hay, W. W., 1977. Calcareous nannofossils. In Ramsay, A. T. S. (Ed.), Oceanic Micropaleontology, (Vol. 2): New York (Academic Press), pp. $1055-1200$.

Hays, J. D., Cook, H. E., III, Jenkins, D. G., Cook, F. M., Fuller, J. T., Goll, R. M., Milow, E. D., and Orr, W. N., 1972. Site 77. In Hays, J. D., et al., Init. Repts. DSDP, 9: Washington (U.S. Govt. Printing Office), $-43-208$.

Keigwin, L. D., and Keller, G., in press. Middle Oligocene climatic range from equatorial Pacific DSDP Site 77B. Geology.

Keller, G., 1981. Miocene biochronology and paleoceanography of the North Pacific. Mar. Micropal., 6:535-551.

Keller, G., and Barron, J., 1982. Paleoceanographic implications of Miocene deep sea hiatuses. Geol. Soc. Am. Bull., 94:590-613.

Kennett, J. P., Houtz, R. E., Andrews, P. B., Edwards, A. R., Gostin, V. A., Hajos, M., Hampton, M., Jenkins, D. G., Margolis, S. V., Ovenshine, A. T., and Perch-Nielsen, K., 1975. Cenozoic paleoceanography in the southwest Pacific Ocean, Antarctic glaciation, and the development of the circum-Antarctic current. In Kennett, J. P., Houtz, R. E., et al., Init. Repts. DSDP, 29: Washington (U.S. Govt. Printing Office), 1155-1169.

Lohmann, G. P., and Carlson, J. J., 1981. Oceanographic significance of Pacific late Miocene calcareous nannoplankton. Mar. Micropal., 6:553-579.

Martini, E., 1971. Standard Tertiary and Quaternary calcareous nannoplankton zonation. Proc. Second Planktonic Conf., pp. 739-785.

Okada, H., and Bukry, D., 1980. Supplementary modification and introduction of code numbers to the low-latitude coccolith biostratigraphic zonation (Bukry, 1973-1975). Mar. Micropal., 5:321-325.
Okada, H., and McIntyre, A., 1977. Modern coccolithophores of the Pacific and North Atlantic Oceans. Micropaleontology, 23:1-55.

Perch-Nielsen, K., 1971. Elektronen mikroskopische Untersuchungen an Coccolithen und verwandten Formen aus dem Eozän von Dänemark. Biol. Skr. K. Dan. Vidensk. Selsk., 18:1-76.

Roth, P. H., 1973. Calcareous nannofossils. Leg 17, Deep Sea Drilling Project. In Winterer, E. L., Ewing, J. I., et al., Init. Repts. DSDP, 17: Washington (U.S. Govt. Printing Office), 695-795.

Roth, P. H., and Coulbourn, W. T., 1982. Floral and solution patterns of coccoliths in surface sediments of the North Pacific. Mar. Micropal., 7:1-52.

van Andel, T. H., Heath, G. R., and Moore, Jr., T. C., 1975. Cenozoic history and paleoceanography of the central equatorial Pacific ocean. Mem. Geol. Soc. Am., 143:1-134.

Wirrmann, D., 1980. Les sédiments superficiels de la zone "ClarionClipperton" (Pacifique tropical nord): sédimentologie-minéralogie [Thèse $3^{\circ}$ cycle]. Université Louis Pasteur, Strasbourg.

Woodruff, F., Savin, S. M., and Douglas, R. G., 1981. Miocene stable isotope record: a detailed Pacific ocean study and its paleoclimatic implications. Science, 212:665-668.

Date of Initial Receipt: 25 October 1983

Date of Acceptance: 22 April 1984

\section{APPENDIX \\ Nannofossil Taxa Found at Leg 85 Sites}

Cyclicargolithus abisectus (Müller, 1970) Bukry, 1973

Ceratolithus acutus Gartner and Bukry, 1974

Chiasmolithus altus Bukry and Percival, 1971

Helicopontosphaera ampliaperta (Bramlette and Wilcoxon, 1967) Bukry, 1970

Dictyococcites antarctica Haq, 1976

Discoaster asymmetricus Gartner, 1969

Discoaster aulakos Gartner, 1967

Discoaster barbadiensis Tan, 1927

Sphenolithus belemnos Bramlette and Wilcoxon, 1967

Discoaster bellus Bukry and Percival, 1971

Discoaster berggrenii Bukry, 1971

Dictyococcites bisectus (Hay, Mohler, and Wade, 1966) Bukry and Percival, 1971

Discoaster blackstockae Bukry, 1973

Discoaster bollii Martini and Bramlette, 1963

Discoaster braarudi Bukry, 1971

Discoaster brouweri Tan, 1927

Discoaster calcaris Gartner, 1967

Triquetrorhabdulus carinatus Martini, 1965

Discoaster challengeri Bramlette and Riedel, 1954

Discoaster ciperoensis $=$ Discoaster $\mathrm{sp}$. (ciperoensis group) Martini, 1965

Sphenolithus ciperoensis Bramlette and Wilcoxon, 1967

Rhabdosphaera clavigera Murray and Blackman, 1898

Helicopontosphaera compacta (Bramlette and Wilcoxon, 1967) Hay, 1970

Sphenolithus conicus Bukry, 1971

Ceratolithus cristatus Kamptner, 1954

Reticulofenestra daviesi (Haq, 1968) Haq, 1971

Discoaster decorus (Bukry, 1971) Bukry, 1973

Discoaster deflandrei Bramlette and Riedel, 1954

Amaurolithus delicatus Gartner and Bukry, 1975

Discoaster dilatus Hay, 1967

Sphenolithus dissimilis Bukry and Percival, 1971

Sphenolithus distentus (Martini, 1965) Bramlette and Wilcoxon, 1967

Pontosphaera distincta (Bramlette and Sullivan, 1961) Burns, 1973

Reticulofenestra doronicoides (Black and Barnes, 1961) n. comb.

Coccolithus eopelagicus (Bramlette and Riedel, 1954) Bramlette and Sullivan, 1961

Helicopontosphaera euphratis (Haq, 1966) Martini, 1969

Discoaster exilis Martini and Bramlette, 1963

Coccolithus fenestratus (Deflandre and Fert, 1968) Bukry, 1971

Cyclicargolithus floridanus (Roth and Hay, 1967) Bukry, 1971

Cyclococcolithina formosa (Kamptner, 1963) Wilcoxon, 1970

Reticulofenestra gartneri Roth and Hay, 1967 


\section{A. PUJOS}

Reticulofenestra gelida (Geitzenauer, 1972) Backman, 1978

Discoaster gemmifer Stradner, 1961

Helicopontosphaera granulata Bukry and Percival, 1971

Discoaster hamatus Martini and Bramlette, 1963

Reticulofenestra haqii Backman, 1978

Dictyococcites hesslandi (Haq, 1966) Haq and Lohmann, 1976

Sphenolithus heteromorphus Deflandre, 1953

Reticulofenestra hillae Bukry and Percival, 1971

Reticulofenestra insignita Roth and Hay, 1967

Discoaster intercalaris Bukry, 1971

Helicopontosphaera intermedia (Martini, 1965) Hay and Mohler, 1967

Discolithina japonica Takayama, 1967

Helicopontosphaera kamptneri Hay and Mohler, 1967

Discoaster kugleri Martini and Bramlette, 1963

Pseudoemiliania lacunosa (Kamptner, 1963) Gartner, 1969

Cyclococcolithina leptopora (Murray and Blackman, 1898) Wilcoxon, 1970

Discoaster lidzi Hay, 1967

Discoaster loeblichii Bukry, 1971

Cyclococcolithina macintyrei (Bukry and Bramlette, 1969) Bukry, 1973

Triquetrorhabdulus milowii Bukry, 1971

Reticulofenestra minuta Roth, 1970

Reticulofenestra minutula (Gartner, 1967) Haq and Berggren, 1978

Coccolithus miopelagicus Bukry, 1971

Discoaster moorei Bukry, 1971

Sphenolithus moriformis (Brönnimann and Stradner, 1960) Bramlette and Wilcoxon, 1967

Discolithina multipora (Kamptner, 1948) Martini, 1965

Sphenolithus neoabies Bukry and Bramlette, 1969

Discoaster neohamatus Bukry and Bramlette, 1969

Pyrocyclus orangensis (Bukry, 1971) Backman, 1980

Pontosphaera pacifica Burns, 1973

Discoaster pansus (Bukry and Percival, 1971) Bukry, 1973

Coccolithus pelagicus (Wallich, 1877) Schiller, 1930

Discoaster pentaradiatus Tan, 1927

Discoaster perclarus Hay, 1967
Sphenolithus predistentus Bramlette and Wilcoxon, 1967

Amaurolithus primus (Bukry and Percival, 1971) Gartner and Bukry, 1975

Dictyococcites producta (Kamptner, 1963) Backman, 1980

Sphenolithus pseudoradians Bramlette and Wilcoxon, 1967

Reticulofenestra pseudoumbilica (Gartner, 1967) Gartner, 1969

Discoaster pseudovariabilis Martini and Worsley, 1971

Discoaster quinqueramus Gartner, 1969

Coccolithus radiatus Kamptner, 1955

Cyclicargolithus reticulatus (Gartner and Smith, 1967) Bukry, 1971

Geminilithella rotula (Kamptner, 1956) Backman, 1980

Ceratolithus rugosus Bukry and Bramlette, 1968

Triquetrorhabdulus rugosus Bramlette and Wilcoxon, 1967

Discoaster saipanensis Bramlette and Riedel, 1954

Discoaster saundersi Hay, 1967

Helicopontosphaera sellii Bukry and Bramlette, 1969

Orthorhabdus serratus Bramlette and Wilcoxon, 1967

Bramletteius serraculoides Gartner, 1969

Discoaster signus Bukry, 1971

Discoaster stellutus Gartner, 1967

Ellipsolithus subdistichus Roth and Hay, 1967

Discoaster sublodoensis Bramlette and Sullivan, 1961

Discoaster subsurculus Gartner, 1967

Discoaster surculus Martini and Bramlette, 1963

"Reticulofenestra" tagana (Fonseca, 1976) n. comb.

Discoaster tamalis Kamptner, 1967

Discoaster tani Bramlette and Riedel, 1954

Amaurolithus tricorniculatus (Gartner, 1967) Gartner and Bukry, 1975

Discoaster triradiatus Tan, 1927

Discoaster tristellifer Bukry, 1976

Reticulofenestra umbilica (Levin, 1965) Martini and Ritzkowski, 1968

Pontosphaera vadosa Hay, Mohler, and Wade, 1966

Discoaster variabilis Martini and Bramlette, 1963

Coronocyclus sp.

Scyphosphaera $\mathrm{sp}$.

Syracosphaera sp. 


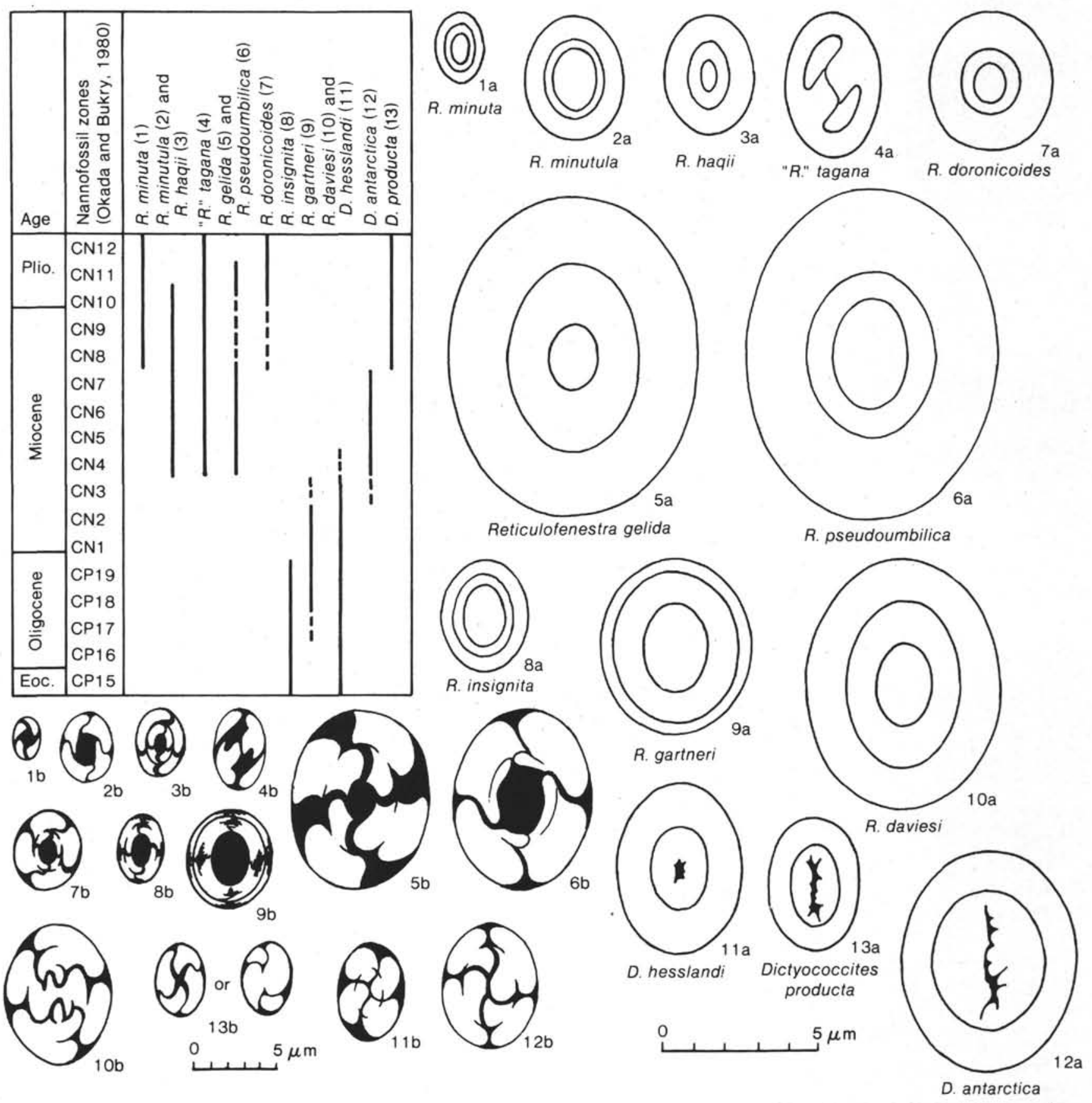

Plate 1. The small- and medium-sized Reticulofenestra and Dictyococcites in the Cenozoic sequence of Leg 85 . 1a, b. Reticulofenestra minuta.

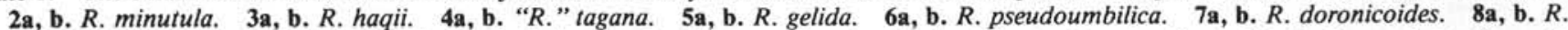
insignita. $9 \mathrm{a}, \mathbf{b} . R$. gartneri. $10 \mathrm{a}, \mathbf{b} . R$. daviesi. 11a, b. Dictyococcites hesslandi. 12a, b. D. antarctica. 13a, b. D. producta. $(\mathrm{a}=$ archetype-scheme of the coccolith; $b=$ figure in polarized light.) 

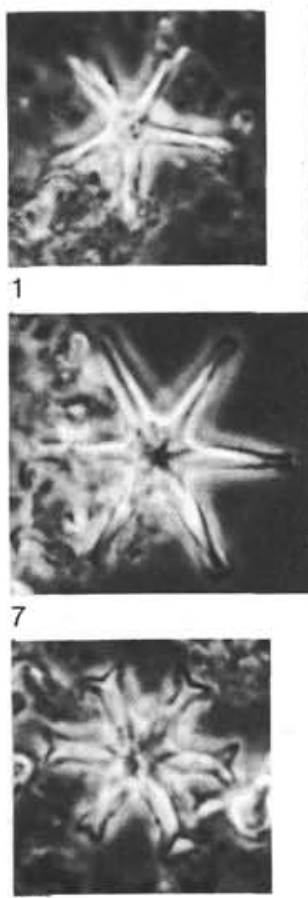

13

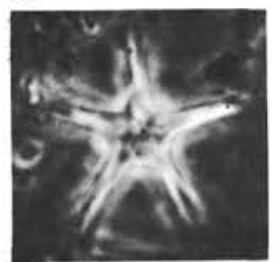

19

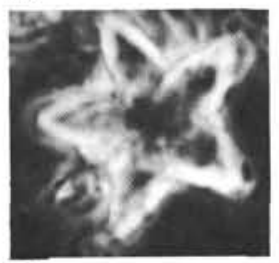

25

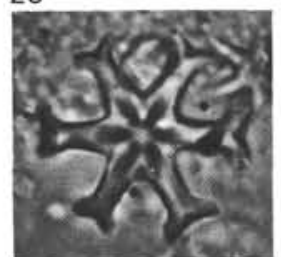

33
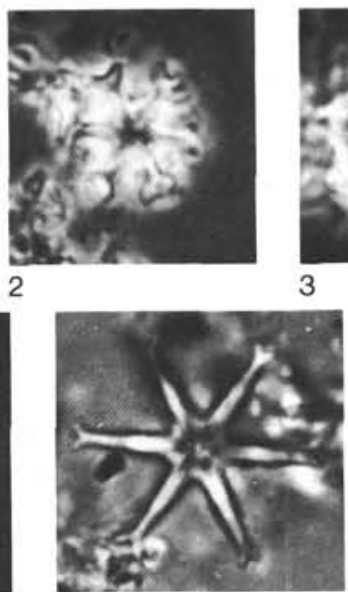

8

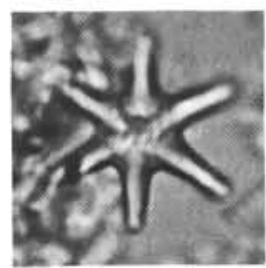

14

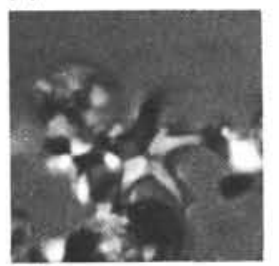

20

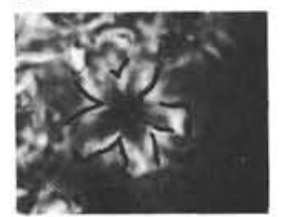

26

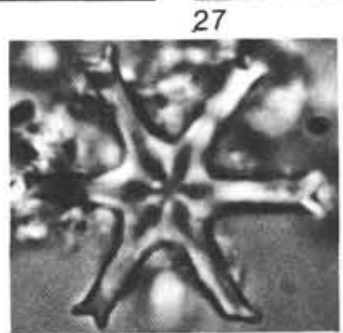

34

3

9

15

21

27
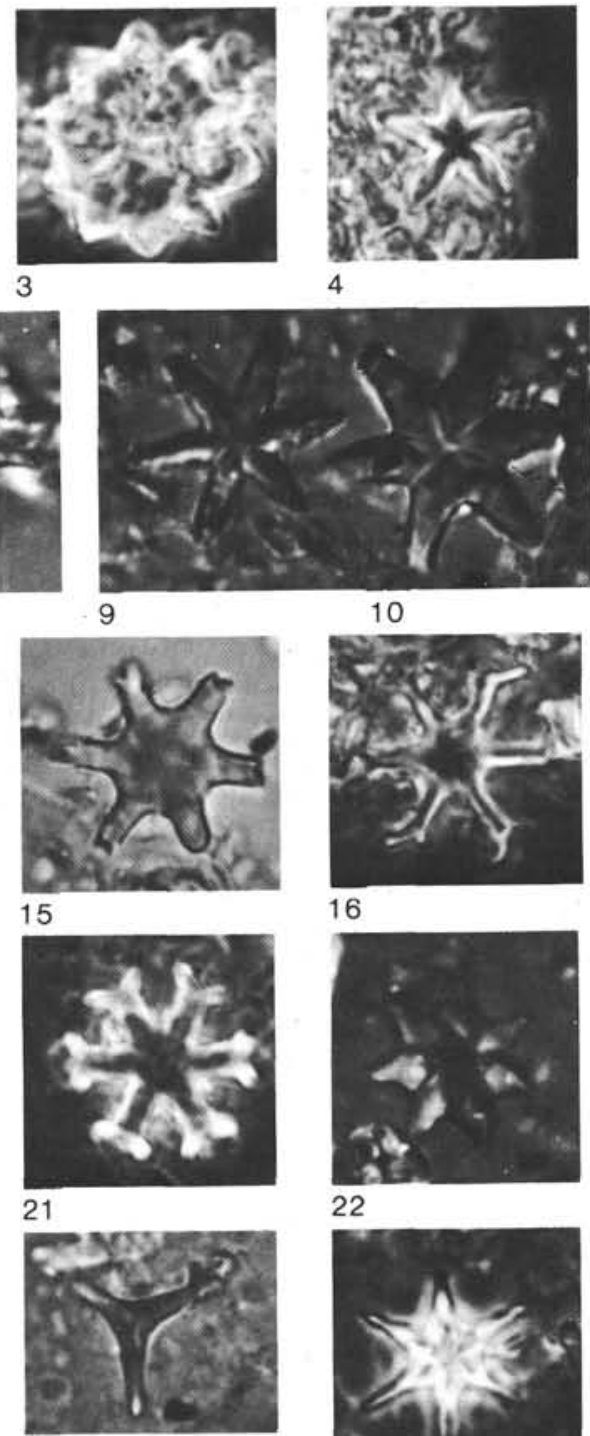

16

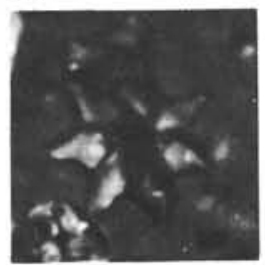

22

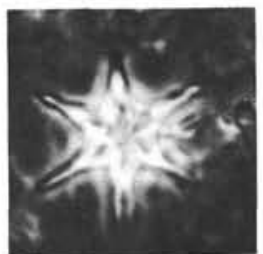

28

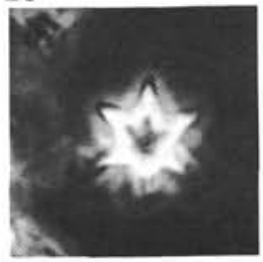

31

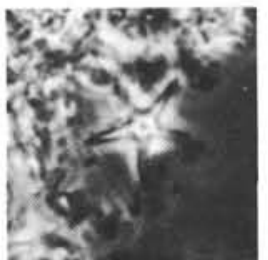

5

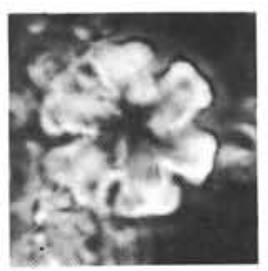

11

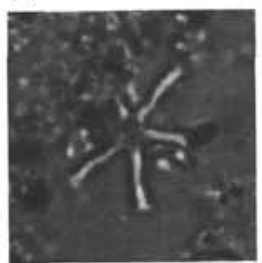

17

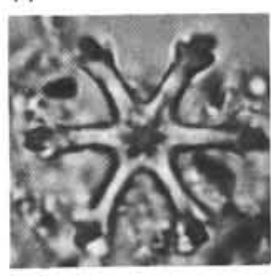

23

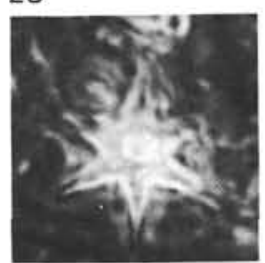

29

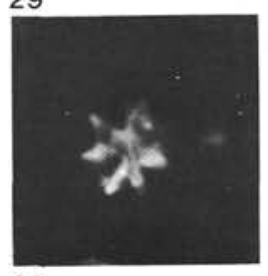

32

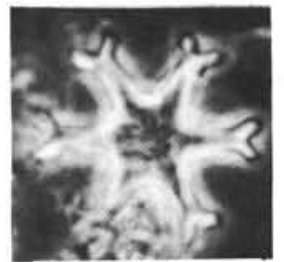

6

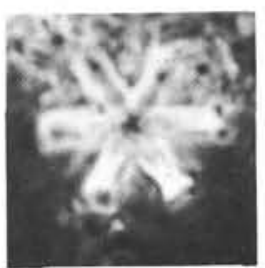

12

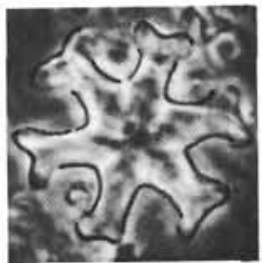

18

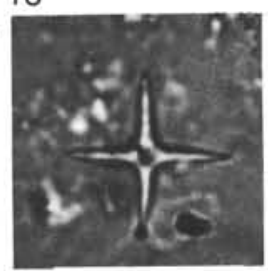

24

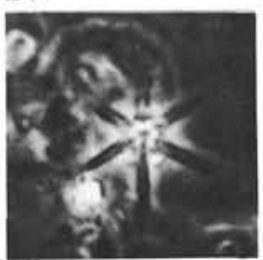

30

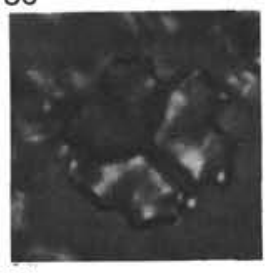

35

Plate 2. (About $\times 1300$; unless stated otherwise, the photographs were taken with a Nomarski interferential system.) 1. Discoaster asymmetricus, 572A-6-6, 0-1 cm (CN12a). 2. D. aulakos, 572A-14-3, 0-1 cm (CN9a). 3. D. barbadiensis, 573B-42-4, 135 cm (CP15). 4. D. bellus, 573B-4-3, 15-16 cm (CN7). 5. D. berggrenii, 573-12-4, 0-1 cm (CN9a). 6. D. bollii, 572A-14-3, 0-1 cm (CN9b). 7. D. brouweri, 573-7-2, 0-1 cm (CN12a). 8. D. calcaris, 573-7-2, 0-1 cm (CN12a). 9. D. ciperoensis, bright field, $574-2-6,100-101 \mathrm{~cm}(\mathrm{CN} 12 \mathrm{a})$. 10. D. druggi, bright field, $574-2-6,100-101 \mathrm{~cm}(\mathrm{CN} 12 \mathrm{a})$. 11. D. deflandrei, 573B-12-5, $15-16 \mathrm{~cm}$ (CN3). 12. D. dilatus, 573B-4-3, 15-16 cm (CN7). 13. D. exilis, $574-4-4,27-28 \mathrm{~cm}(\mathrm{CN} 10 \mathrm{c})$. 14. D. intercalaris, bright field, $572 \mathrm{D}-7-3,55-56 \mathrm{~cm}(\mathrm{CN} 8 \mathrm{a})$. 15. D. kugleri, bright field, $572 \mathrm{D}-21-3,47-48 \mathrm{~cm}$ (CN5b). 16. D. loeblichii, 573B-2-3, $15-16 \mathrm{~cm}$ (CN8a). 17. D. moorei, bright field, 574-13-4, 49-50 cm (CN5a). 18. D. pansus, 574-4-3, 27-28 cm (CN11). 19. D. pentaradiatus, 574-4-5, 27-28 cm (CN10b). 20. D. pentaradiatus, polarized light, 573-7-3, 0-1 cm (CN12a). 21. D. pseudovariabilis, 573B-2-3, 15-16 cm (CN8a). 22. D. saipanensis, bright field, $573 \mathrm{~B}-42-4,116 \mathrm{~cm}$ (CP15). 23. D. surculus, bright field, 572D-10-3, 55-56 cm (CN8a). 24. D. tamalis, bright field, 574-2-6, 100-101 cm (CN12a). 25. D. tani, 573B-18-2, 15-16 cm (CN1c). 26. D. tani, 574C-35-1, 13-14 cm (CP15). 27. D. triradiatus, 574-2-5, 100-101 cm (CN12c). 28. D. tristellifer, 574-4-4, 27-28 cm, low focus (CN10c). 29. D. tristellifer, $574-4-5,27-28 \mathrm{~cm}$, middle focus (CN10b). 30. D. tristellifer, 574-4-4, 27-28 cm, high focus (CN10c). 31.0 . tristellifer, 573-8-7, 0-1 cm, slightly dissolved specimen (CN10). 32. D. tristellifer, polarized light, 573-7-3, 0-1 cm, very dissolved specimen (CN12a). 33. D. variabilis, bright field, $574-4-3,27-28 \mathrm{~cm}$ (CN11). 34. D. decorus, bright field, 573-7-4, 0-1 cm (CN11). 35. Undetermined etched discoaster. 

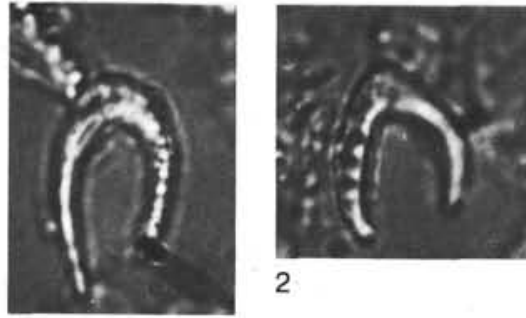

2

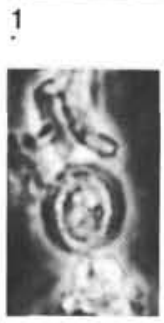

7

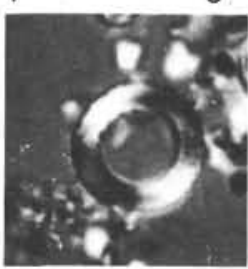

13

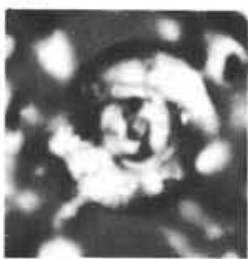

21

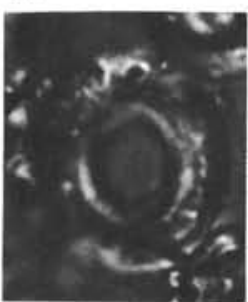

27

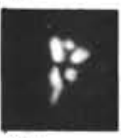

33

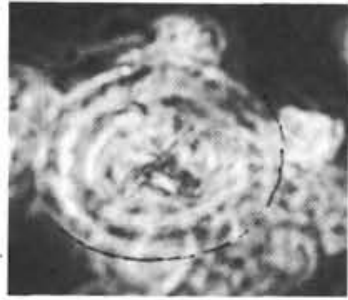

8

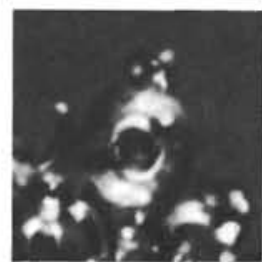

14

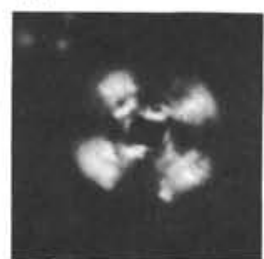

22

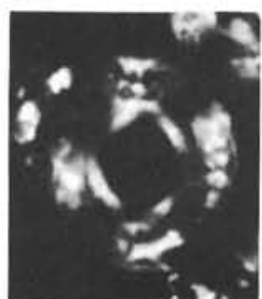

28

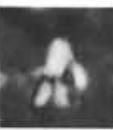

34
35
36

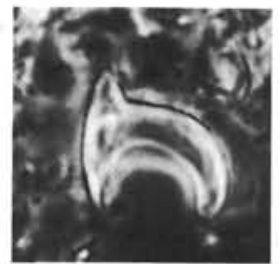

3

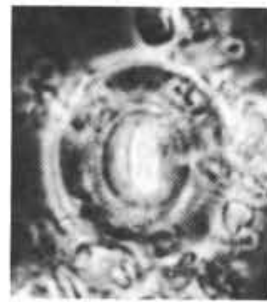

9

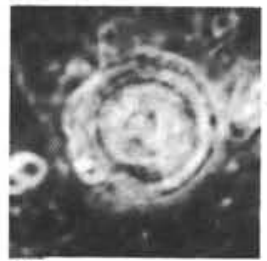

15

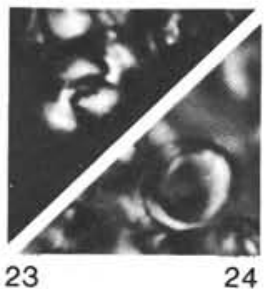

23

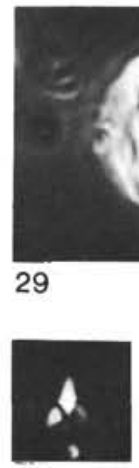

37

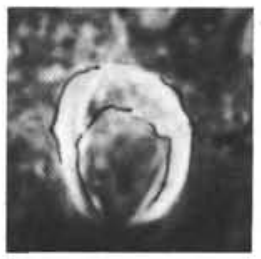

4

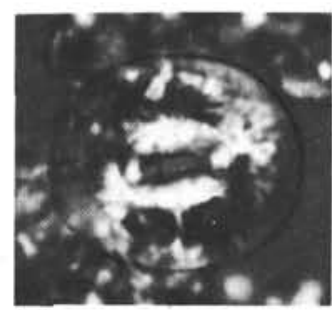

10

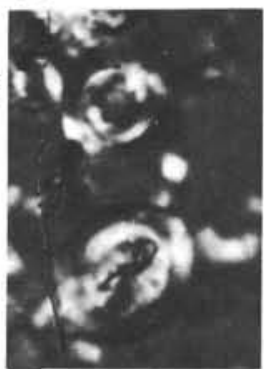

17

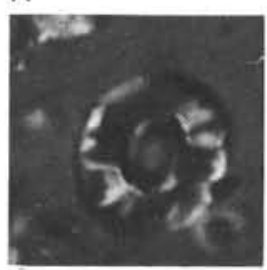

25

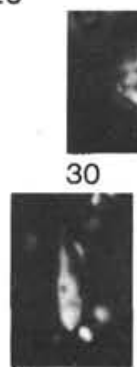

39

5

40.
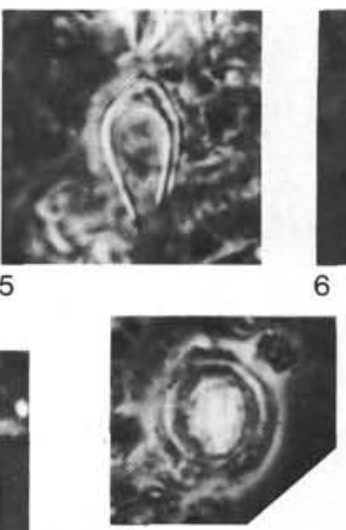

11

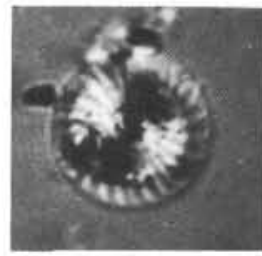

18

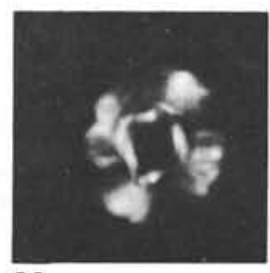

26

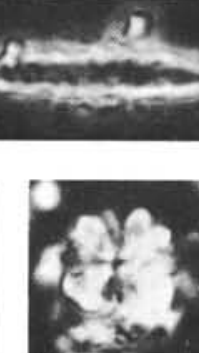

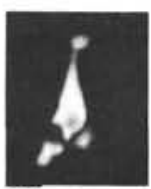

38

Plate 3. (About $\times 1300$; unless stated otherwise, the photographs were taken with a Nomarski inferential system.) 1. Ceratolithus cristatus, bright field, 575-1-3, 140-141 cm (CN12d). 2. Amaurolithus amplificus, bright field, 575-1-3, 140-141 cm (CN12d), 3. Amaurolithus tricorniculatus, 574-4-5, 27-28 cm (CN10b). 4. Amaurolithus primus, 573-10-5, 0-1 cm (CN10). 5. Amaurolithus delicatus, 574-4-4, 27-28 cm (CN10c). 6. Ceratolithus rugosus, bright field, 574-2-4, 100$101 \mathrm{~cm}(\mathrm{CN} 12 \mathrm{c})$. 7. Ellipsolithus subdistichus, 573B-38-3, 27-28 cm (CP16). 8. Chiasmolithus altus, 573B-38-3, 27-28 cm (CP16c). 9. Coccolithus eopelagicus, 573B-30-3, 15-16 cm (CP18). 10. Coccolithus miopelagicus, polarized light, 573B-5-3, 15-16 cm (CN6). 11. Coccolithus pelagicus, 572A-14-3, 0-1 cm (CN9b). 12. Coccolithus radiatus, 573B-18-2, 15-16 cm (CN1c). 13. Coronocyclus sp., bright field, 575A-6-2, 51-52 cm (CN2). 14. Cyclicargolithus floridanus, polarized light, 573B-13-3, 15-16 cm (CN3). 15. Cyclococcolithina formosa, 573B-42-4, 135-136 cm (CP15). 16. Cyclococcolithina formosa, polarized light, 573B-42-2, $50-51 \mathrm{~cm}$ (CP15). 17. Dictyococcites bisectus, polarized light, 573B-42-2, 50-51 cm (CP15). 18. Cyclococcolithina macintyrei, bright field, $573-10-3,0-1 \mathrm{~cm}$ (CN10): 19. Discolithina multipora, 572D-27-3, 55-56 cm (CN5a), 20. Reticulofenestra daviesi, 572D-27-3, 55-56 cm (CN5a). 21. Cyclicargolithus abisectus, bright field, 575A-23,CC (CN1b). 22. Cyclicargolithus abisectus, polarized light, 575A-23,CC (CN1b). 23. Pyrocyclus orangensis, polarized light, 573B-27-3, $15-16 \mathrm{~cm}$ (CP18). 24. Pyrocyclus orangensis, bright field, 573B-27-3, 15-16 cm (CP18). 25. Reticulofenestra hillae, bright field, $574 \mathrm{C}-34-2,93-94 \mathrm{~cm}$ (CP15). 26. Reticulofenestra hillae, polarized light, $574 \mathrm{C}-34-2,93-94 \mathrm{~cm}$ (CP15). 27. Reticulofenestra umbilica, bright field, 573B-42-2, 50-51 cm (CP16b). 28. Reticulofenestra umbilica, polarized light, 573B-42-2, 50-51 cm (CP16b). 29. Triquetrorhabdulus milowii, 573B-17-3,15-16 cm (CN1c). 30. Triquetrorhabdulus carinatus, 573B-18-2, 15-16 cm (CN1c). 31. Reticulofenestra pseudoumbilica, 572D-19-3, 47-48 cm (CN5b). 32. Reticulofenestra pseudoumbilica, polarized light, $572 \mathrm{D}-19-3,47-48 \mathrm{~cm}$ (CN5b). 33. Sphenolithus belemnos, polarized light, 575A-8-2, 51-52 cm (CN2). 34. Sphenolithus belemnos, bright field, 575A-6-2, 51$52 \mathrm{~cm}(\mathrm{CN} 2)$. 35. Sphenolithus conicus, polarized light, 573B-21-2, 30-31 cm (CP19), 36. Sphenolithus dissimilis, polarized light, $574 \mathrm{C}-5-4,49-50 \mathrm{~cm}(\mathrm{CN} 1 \mathrm{c})$. 37. Sphenolithus distentus, polarized light, 573B-23-3, 35-36 cm (CP19). 38. Sphenolithus heteromorphus, polarized light, $574-28-2,49-50 \mathrm{~cm}$ (CN4). 39. Sphenolithus predistentus, polarized light, 573B-38-3, 27-28 cm (CP16c). 40. Sphenolithus moriformis, polarized light, $575 \mathrm{~A}-6-2,51-52 \mathrm{~cm}$ (apical view) (CN2). 41. Sphenolithus moriformis, polarized light, $575 \mathrm{~A}-6-2,51-52 \mathrm{~cm}$ (lateral view) (CN2). 